Review

\title{
Developments and Challenges for mAb-Based Therapeutics
}

\section{Sumit Goswami ${ }^{1}$, Wei Wang ${ }^{1}$, Tsutomu Arakawa ${ }^{2, *}$ and Satoshi Ohtake ${ }^{1}$}

1 Pfizer, Pharmaceutical R\&D - BioTherapeutics Pharmaceutical Sciences, 700 Chesterfield Parkway West, Chesterfield, MO 63017, USA

2 Alliance Protein Laboratories, 6042 Cornerstone Ct West, Suite A1, San Diego, CA 92121, USA

* Author to whom correspondence should be addressed; E-Mail: Tarakawa2@aol.com; Tel.: +1-858-550-9401, Fax: +1-858-550-9403.

Received: 23 May 2013; in revised form: 18 July 2013 / Accepted: 2 August 2013 /

Published: 16 August 2013

\begin{abstract}
The continuous increase in the number of approved monoclonal antibody $(\mathrm{mAb})$-based therapy suggests that mAbs, and their derivatives, will continue to be the focus of the biotherapeutics industry for years to come. Although vast improvements in our capability to manufacture, characterize, and stabilize mAbs have been achieved, there are still challenges to be overcome. These include analytical and stabilization approaches associated with the development of high concentration mAb formulations. In addition, several mAb-based modalities are under development, including antibody drug conjugates (ADCs), fusion proteins, and bispecific antibodies (bsAbs), all designed to overcome the limitations encountered with mAb therapy. The current status of their development, with emphasis on manufacturing challenges as well as preliminary clinical results, will be reviewed.
\end{abstract}

Keywords: monoclonal antibody; fusion-proteins; antibody drug conjugates; fragments; bi-specific

\section{Introduction}

Antibodies are the first line of our body's defense for fighting infectious diseases. Immunized serum and intravenous immunoglobulin (IVIG) have been widely used to treat patients suffering from immunoglobulin deficiency and infectious diseases [1,2]. The invention of monoclonal antibody $(\mathrm{mAb})$ and recombinant technologies has drastically changed the therapeutic utility of antibodies. AB89 (murine mAb) was the first antibody reported to be administered to a patient in USA for the 
treatment of non-Hodgkin's lymphoma [3]. The development of hybridoma technology has enabled a consistent production of mAbs at large scale, paving the way for development of various therapeutic antibodies [4]. The first commercial mAb drug product was OKT3, which suffered from short half-life and immunogenicity due to its non-human nature, and was subsequently withdrawn [5]. Further progress in biotechnology has allowed the successful production of fully human antibodies.

Antibodies, like other proteins, are not very stable relative to small molecule drugs; for example, mAbs possess potential for self-association (aggregation). Because of the relatively high dose required for efficacy, they are often prepared at an extremely high concentration, which further enhances self-association, and as a consequence, may lead to high viscosity and difficulty in handling/processing. In addition, their large size and surface-exposed functional groups are a major source of several chemical degradation pathways. These are only a subset of the challenges currently encountered in the development of antibody therapeutics.

This review covers the current state of $\mathrm{mAb}$ development and its expansion into other mAb-based modalities, which utilizes the specificity of antibodies for antigen binding or the unique properties of antibody Fc domain. The examples include antibody-drug conjugate (ADC), fusion proteins, antibody fragments, and miscellaneous mAb-based modalities, which have been produced with the aim of greater potency, increase in circulation half-life, expanded function, specific delivery of drugs and effector proteins to the site of action, and enhanced tissue penetration. Table 1 lists the milestones of regulatory approvals of mAb-based therapeutics.

Table 1. Milestones of regulatory approval of monoclonal antibody (mAb)-based therapeutics.

\begin{tabular}{|c|c|c|c|c|c|c|}
\hline Year & $\begin{array}{l}\text { Molecule } \\
\text { name }\end{array}$ & $\begin{array}{l}\text { Brand } \\
\text { name }\end{array}$ & $\begin{array}{c}\text { Target } \\
\text { antigen }\end{array}$ & $\begin{array}{c}\text { Primary } \\
\text { Indication }\end{array}$ & $\begin{array}{c}\text { Antibody } \\
\text { type }\end{array}$ & Comment \\
\hline 1986 & Muromonab & Orthoclone ${ }^{\circledR}$ & CD3 & $\begin{array}{l}\text { Acute transplant } \\
\text { rejection }\end{array}$ & $\begin{array}{l}\text { Murine, } \\
\text { IgG2a }\end{array}$ & $\begin{array}{l}\text { First ever Ab } \\
\text { approved by } \\
\text { FDA; later } \\
\text { withdrawn [6] }\end{array}$ \\
\hline 1991 & Nebacumab & Centoxin ${ }^{\circledR}$ & $\begin{array}{l}\text { Endotoxin } \\
\text { (HA-1A) }\end{array}$ & $\begin{array}{l}\text { Sepsis and Gm- } \\
\text { ve bacteraemia }\end{array}$ & $\begin{array}{c}\text { Human } \\
\text { hybridoma } \\
\text { derived IgM }\end{array}$ & $\begin{array}{l}\text { First human mAb } \\
\text { to be approved by } \\
\text { regulatory agency } \\
\text { (Europe); later } \\
\text { withdrawn from } \\
\text { the market }[7,8]\end{array}$ \\
\hline 1993 & Abciximab & ReoPro® & GPIIb/IIIa & $\begin{array}{c}\text { Cardiac } \\
\text { ischemia, stroke, } \\
\text { myocardial } \\
\text { infarction }\end{array}$ & $\begin{array}{c}\text { Chimeric } \\
\text { Fab of IgG1 }\end{array}$ & $\begin{array}{l}\text { First approved } \\
\text { Fab-based } \\
\text { therapeutic [9] }\end{array}$ \\
\hline 1997 & Rituximab & Rituxan® & CD20 & $\begin{array}{l}\text { Non-Hodgkin's } \\
\text { lymphoma }\end{array}$ & $\begin{array}{l}\text { Chimeric } \\
\text { IgG1 }\end{array}$ & $\begin{array}{l}\text { First approved full } \\
\text { length chimeric } \\
\text { mAb }[10,11]\end{array}$ \\
\hline 1997 & Daclizumab & Zenapax® & $\mathrm{CD} 25$ & $\begin{array}{l}\text { Prevention of } \\
\text { kidney } \\
\text { transplant } \\
\text { rejection }\end{array}$ & $\begin{array}{l}\text { Humanized } \\
\text { IgG1 }\end{array}$ & $\begin{array}{c}\text { First approved } \\
\text { full length } \\
\text { humanized mAb } \\
{[12]}\end{array}$ \\
\hline 1998 & Etanercept & Enbrel® & $\begin{array}{l}\text { TNF- } \\
\text { receptor }\end{array}$ & RA & $\begin{array}{l}\text { TNFR2-Fc } \\
\text { fusion }\end{array}$ & $\begin{array}{l}\text { First approved } \mathrm{Fc} \\
\text { fusion protein [9] }\end{array}$ \\
\hline
\end{tabular}


Table 1. Cont.

\begin{tabular}{|c|c|c|c|c|c|c|}
\hline Year & Molecule name & $\begin{array}{l}\text { Brand } \\
\text { name }\end{array}$ & $\begin{array}{c}\text { Target } \\
\text { antigen }\end{array}$ & Indication & $\begin{array}{c}\text { Antibody } \\
\text { type }\end{array}$ & Comment \\
\hline 2000 & $\begin{array}{l}\text { Gemtuzumab } \\
\text { Ozogamicin }\end{array}$ & Mylotarg® & CD33 & $\begin{array}{c}\text { Acute } \\
\text { myelogenous } \\
\text { leukaemia }\end{array}$ & Human IgG4 & $\begin{array}{c}\text { First ADC to be } \\
\text { approved in US; } \\
\text { withdrawn from } \\
\text { the market } \\
{[13,14]}\end{array}$ \\
\hline 2002 & Adalimumab & Humira ${ }^{\circledR}$ & $\mathrm{TNF} \alpha$ & RA & Human IgG1 & $\begin{array}{l}\text { First human } \\
\text { mAb to be } \\
\text { approved in } \\
\text { USA [12] }\end{array}$ \\
\hline 2009 & Catumaxomab & Removab® & $\begin{array}{c}\text { EpCAM on } \\
\text { tumor cells } \\
\text { and CD3 on } \\
\text { T-cells }\end{array}$ & Malignant ascites & $\begin{array}{l}\text { CD3- and } \\
\text { EPCAM- } \\
\text { specific } \\
\text { mouse-rat } \\
\text { hybrid }\end{array}$ & $\begin{array}{l}\text { First bispecific } \\
\text { to be approved } \\
\text { by EMA }[12,15]\end{array}$ \\
\hline
\end{tabular}

\section{2. $\mathbf{m A b}$}

\subsection{Structure, Type, and Function}

Antibodies (Abs) are biological macromolecules naturally produced by the immune system. Molecular structure is composed of four polypeptide chains (two heavy chains of molecular weight $\sim 50 \mathrm{kDa}$ each, and two light chains of molecular weight $\sim 25 \mathrm{kDa}$ each). The heavy chain contains four structural domains; three constant domains ( $\mathrm{CH} 1, \mathrm{CH} 2 \& \mathrm{CH} 3)$ and one variable domain $(\mathrm{VH})$. On the other hand, the light chain is composed of two structural domains; one constant (CL) and one variable (VL). A detailed description of the antibody structure has been provided in the review article by Wang et al. [16]. Based on the sequence of the constant region of the heavy chain, antibodies are divided into five classes: $\operatorname{IgM}, \operatorname{IgD}$, IgG, IgE, and $\operatorname{Ig} A$ [14]. IgGs are further classified as $\operatorname{IgG} 1, \operatorname{IgG} 2$, $\mathrm{IgG} 3$, and $\mathrm{IgG} 4$, in the order of their relative abundance in plasma. Each of these also contains different heavy chains: $\gamma 1, \gamma 2, \gamma 3$, and $\gamma 4$, respectively [16]. Ab-based therapy was first utilized for the treatment of cancer; initially focused primarily against lymphoma and leukemia, however it was also used for the treatment of solid tumors, such as melanoma [17]. The first antibody to be administered to a patient (suffering from non-Hodgkin's lymphoma) was Ab-89 [3]. Although the treatment was not successful, the study demonstrated (for the first time) the feasibility of Ab-based of therapy in the treatment of cancer that demonstrates an acceptable safety profile.

Next, the advent of hybridoma technology allowed the production of monoclonal antibody (mAb) that could be utilized for targeted therapy, owing to its increased specificity towards a target antigen. mAbs are primarily composed of two major functional units. One is the constant fragment (Fc), and the other is the fragment of antigen binding (Fab). Fab unit contains three hypervariable complementarity determining regions (CDRs), which together form the antigen binding site on the surface of the antibody. The major issue with murine mAbs is their low half-life and immunogenicity, despite achieving specific targeting [5]. In chimeric antibodies, the murine variable domain is fused 
with the human constant domain [12]. There are different ways by which humanized antibodies are created. One of the most common methods is to graft mouse CDRs onto human acceptor antibody framework. Fully human antibodies, on the other hand, are either naturally obtained, recombinantly expressed, or collected from transgenic mouse, in which the immune repertoire has been replaced by the human genes $[18,19]$. Another effective way of producing human antibody is phage display [20].

The primary mode of action for mAb-based therapeutics for the treatment of cancer has been considered to be antibody derived cell-mediated cytotoxicity (ADCC). According to this mechanism, the $\mathrm{Fc}$ portion interacts with $\mathrm{FC}_{\gamma}$-receptors on the surface of the effector immune cells (such as monocyte and macrophages), while the antibody is bound to the surface antigen of the cancer cell through its Fab region, and results in ADCC response [21,22]. For example, cetuximab, which binds to the epidermal growth factor receptor (EGFR) antigen on the surface of the tumor cells, is known to mediate its anti-tumor activity through ADCC [23]. Another important mode of action is direct interference of specific cell signaling pathways. For example, bevacizumab binds to the soluble vascular endothelial growth factor (VEGF), and thus inhibits angiogenesis, which is important for the maintenance of tumor vasculature and tumor health [24]. There are also other mechanisms that are worth mentioning, including induction of phagocytosis, complement activation, and activation of T-cell immunity. A thorough description of various modes of action applicable to therapeutic antibody can be found elsewhere [25].

1986 remains a historical year, as it witnessed the first approval of mAb-based therapy by the FDA, Muromonab (Orthoclone ${ }^{\circledR}$, anti-CD3); a murine-type mAb, which was later withdrawn by the FDA [26] (Table 1). In 1997, the first full length chimeric monoclonal antibody, rituximab, was approved by the FDA (anti-CD20 on the surface of B-lymphocytes) for the treatment of cancer [27], which is still marketed today. This drug is currently being utilized as a single agent (for induction and maintenance), or in combination with chemotherapeutic agents, for the treatment of various human lymphoma and chronic lymphocytic lymphoma [10,28]. 1997 witnessed the approval of the first humanizd mAb, daclizumab (anti-CD25 specific). The first, fully human mAb, adalimumab (anti-TNF), was not approved by the FDA until 2002 [29].

\subsection{Glycosylation and Its Importance}

Monoclonal antibodies are naturally available in glycoslated form. Glycosylation is an important form of chemical modification. In recent years, the scientific community has gained knowledge regarding the significance of carbohydrate moieties in therapeutic monoclonal antibodies. mAbs are known to contain N-linked glycan residues, connected through Asp $(\mathrm{N})$ residue on the amino acid sequence such as Asn-X-Ser/Thr [30,31]. Asn297 in the $\mathrm{CH} 2$ domain (near the hinge region) is the only conserved glycosylation site in human IgG. The core sequence of the glycan connected to this residue is a heptasaccharide, comprised of $(\mathrm{GlcNAc})_{2}-(\mathrm{Man})_{3}-(\mathrm{GlcNAc})_{2}$. Presence of glycosylation in general is thought to provide structural stability to protein against stress factors, such as thermal stress, and to improve solubility [32]. In fact, the presence of oligosaccharide has been reported to improve the structural integrity of IgG1 mAb [33,34]. Loss of glycosylation may result in increased propensity towards aggregation, as was observed with IFN- $\beta$, which resulted in the formation of insoluble aggregates and loss of activity upon enzymatic deglycosylation [35]. It has been reported that the 
interaction site for FC $\gamma \mathrm{R}$ on the Fc region is located near the hinge domain [36], and glycosylation in the hinge region is critical for mediating interaction between $\mathrm{FC} \gamma \mathrm{R}$ and the $\mathrm{Fc}$ region (i.e., effector function) [36,37]. Activation of FC $\gamma \mathrm{R}$ results in various types of immune responses including: ADCC, antibody-mediated phagocytosis, and secretion of inflammatory modulators [38-40]. Complete deglycosylation of IgG1 results in loss of binding capacity with FC $\gamma \mathrm{R}$ and subsequent loss of effector function [41]. The absence of fucose residue in the Fc-linked glycan moiety has been reported to increase the efficacy of $\mathrm{mAb}$ in initiating the ADCC response at much lower concentrations, which has been attributed to the higher binding affinity of non-fucosylated mAb to the FC $\gamma$ RIIIa receptor [42-44]. High binding affinity allows non-fucosylated $\mathrm{mAb}$ to compete with the binding of serum $\operatorname{IgG}$ to the FC $\gamma$ RIIIa receptor expressed on natural killer cells (NK) [45]. Engineering of expression host cells has allowed the large scale production of non-fucosylated antibodies possible [46]. Recent phase-I clinical trials with two different non-fucosylated mAbs (MEDI-563, a humanized anti-IL-5 receptor IgG1, and KW-0761, a humanized anti-CCR4 IgG1) demonstrated the attainment of high efficacy at low doses [31]; this was attributed to the absence of fucosylation and enhancement of ADCC response [31]. Glycosylation is a process taking place during post-translational modification, and thus, deglycosylation is a consequence of such modification not occurring in the endoplasmic reticulum (ER) during $\mathrm{mAb}$ synthesis. Therefore, achievement of selective defucosylation is challenging and requires careful control of the production process. A number of processes have been proposed for selective defucosylation, including selective inactivation of fucosylation pathway in mammalian cells, enzymatic modification of the N-glycan, and chemical synthesis of the non-fucosylated form of the N-glycan [31].

\subsection{Development of $m A b$ Therapeutics and Associated Challenges}

mAbs possess high level of specificity for their target, and in general, are more efficacious than their small molecule counterpart. The development of mAb-based therapeutics has its own challenges, however. $\mathrm{mAb}$ is a macromolecule, and in general follow similar degradation pattern as with other protein-based biopharmaceuticals [47]. Biological activity of mAb-based therapeutics is closely tied to their structural, conformational, and chemical stability. Degradation may occur at various stages of development starting from bioprocessing and purification to formulation, storage, and delivery. Successful development of mAb-based therapeutics requires a thorough understanding of possible degradation pathways. A number of review articles are available that focus on this topic for mAb-based therapeutics, or protein-based therapeutics in general $[16,48,49]$. Degradation can be broadly classified into two major categories, physical and chemical [50], and will be briefly described below.

\subsubsection{Physical Degradation}

The most common pathway of physical degradation is aggregation, by which two or more monomeric units of mAbs may bind to each other to form higher order oligomeric structures such as dimer, trimer, tetramer, etc., or even larger structures. The size of aggregates can range from nanometers to hundreds of microns. Based on the size range, aggregates have been classified into the following categories: (1) submicron $(<1 \mu \mathrm{m}$ size) particles, which are conventionally referred to as soluble particles; (2) sub-visible particles (1-100 $\mu \mathrm{m}$ size), and (3) visible particles (>100 $\mu \mathrm{m}$ size) [51,52]. 
Sub-visible and visible particles together are referred to as insoluble particles. Particles that belong to the size range of $0.1-1 \mu \mathrm{m}$ are at times referred to as small sub-visible particles [51]. Aggregates can be non-covalent in nature, mediated by weak forces such as hydrophobic interaction, Van der Waals interaction, hydrogen bonding, and electrostatic forces [53]. Covalent interaction (e.g., disulfide linkage and dityrosine linkage) may also lead to the formation of aggregates [54,55]. Various stress factors have been reported to induce aggregation, and the exposure to such stresses may occur during the regular life-cycle of a mAb. Common practice in the biopharmaceutical industry is to assess the relative stability of the compound of interest through its exposure to a range of stress factors in its extremity. The most common stress factors encountered during manufacturing and processing include temperature stress, mechanical stress, and freeze/thaw stress. Exposure to elevated temperature is a common cause for aggregation of mAbs. As accidental temperature excursion may occur during shipping or storage, exposure to elevated temperature is intentionally carried out during stability assessment. At elevated temperature, $\mathrm{mAb}$ may undergo conformational destabilization, or partial-to-complete unfolding, which may lead to the formation of aggregates via non-covalent interactions [48,56]. During frozen storage and shipping, on the other hand, accidental excursion of temperature may lead to unintentional exposure to freeze/thaw cycle. Freeze/thaw causes aggregation via a number of factors such as partitioning of the protein molecule to ice-water interface, adsorption to the container surface (solid-water interface), cryo-concentration, and change in $\mathrm{pH}$ due to non-uniform crystallization of buffer [57-60]. Mechanical stress can be manifested in a number of ways, including agitation, shaking, stirring, pumping, filling, and filtration. These are stresses to which a mAb may be exposed during manufacturing and transport. Formulation conditions such as $\mathrm{pH}$, ionic strength, and concentration of $\mathrm{mAb}$ may also have significant influence on aggregation [61]. Formulation of $\mathrm{mAb}$ at high concentration for subcutaneous (sc) application is of great interest to the pharmaceutical industry, and thus will be described further below.

\subsubsection{Chemical Degradation}

Chemical degradation may occur in a number of different ways. This type of degradation affects the primary sequence and may also lead to significant changes in the higher order structure. Examples of chemical degradation include deamidation, oxidation, isomerization, clipping/fragmentation, and cross-linking [16,47,50]. Deamidation is probably the most common type of chemical degradation encountered in mAb-based biotherapeutics [62-64]. The reaction is favored at neutral and basic $\mathrm{pH}$ [63]. There are examples of deamidation occurring at lower $\mathrm{pH}$, however that has been reported to occur primarily through a mechanism independent of succinimide formation [65]; for example, deamidation of Asn in the A chain of insulin is favored at $\mathrm{pH}<5$, which is mediated via the formation of cyclic anhydride intermediate [66]. There are factors other than $\mathrm{pH}$ that influences the rate of deamidation, e.g., sequence and local structure (steric effect). Amino acids present at the carboxyl end of Asn have been reported to influence the rate of deamidation; the decrease in rate has been correlated with increase in size and branching of the side chain $[63,64]$. Isomerization is another common method of chemical degradation that shares the common outcome with deamidation. It can occur directly from Asp residue or from the succinimide intermediate [67]. Similarly to deamidation, isomerization is favored at neutral and basic $\mathrm{pH}$, and the rate has been reported to be influenced by the steric effect $[63,67]$. 
Hydrolysis of a peptide bond leads to fragmentation of the protein. Some peptide bonds, such as Asp-Gly and Asp-Pro, are sensitive to hydrolysis. Asp-Y sequence has been reported to be 100 times more sensitive to hydrolysis than any other peptide bonds [68,69]. At times, hydrolysis is the natural, subsequent reaction following deamidation of Asn residue, as is observed with insulin [70].

Furthermore, mAbs may contain certain residues that are sensitive to oxidation, such as Met, Tyr, Trp, His, and Cys [62,65,71]. Although not as prevalent as deamidation and isomerization, oxidation has been reported to be the major pathway of degradation for certain proteins, e.g., OKT3 (IgG2), which demonstrated oxidation at several Met residues and free Cys under $5{ }^{\circ} \mathrm{C}$ storage condition [72]. There are several external factors that have been reported to induce oxidation, including exposure to light, contamination with trace amount of transition metal ion, and the presence of degradation product of an excipient (e.g., hydrogen peroxide from polysorbate degradation) [73-75]. The consequence of oxidation may include increase in aggregation [76]. Oxidation is observed most commonly with the Met residue, and the major by-product of such reaction is the formation of sulfoxide and sulfone [77]. Two factors that affect the rate of oxidation are the local structure around the oxidation sensitive group (e.g., surface exposure and steric hindrance) and the solution $\mathrm{pH}$ [73,77]. In some cases, increase in solution $\mathrm{pH}$ has been found to increase the rate of oxidation [78], but $\mathrm{pH}$-dependent increase in oxidation is not a general phenomenon.

Chemical degradation may also result from cross-linking, which may or may not be mediated by the formation of disulfide bond. When cross-linking is disulfide bond-mediated, the reaction occurs either by the formation of a new disulfide bond or by disulfide bond exchange. Intra-molecular disulfide linkage may lead to change in tertiary structure, whereas inter-molecular (or inter-domain) disulfide linkage may lead to change in quaternary structure or formation of covalent aggregates [16,79]. At higher $\mathrm{pH}$, the formation of reactive thiolate ion $\left(\mathrm{S}^{-}\right)$, from the thiol group $(-\mathrm{SH})$ of cys residue, is favored, which may increase the probability of disulfide linkage formation [80]. There are instances of covalent cross-linking that may occur between different amino acid residues besides Cys, which, unlike disulfide linkage, are non-reducible [81].

\subsubsection{Importance of Controlling Degradation}

Successful development of mAb-based therapeutics requires a careful assessment of the various degradation pathways possible for a molecule (both physical and chemical). Degradation of the molecule may interfere with the intended biological activity, as the site of degradation may involve a domain that is critical for biological function. There are cases in which the formation of aggregates was followed by loss of biological activity; for example, the antiviral activity of interferon- $\beta-1 b$ (IFN- $\beta$-1b) aggregate was found to be three times lower than that of its monomer form [35]. Another major impact of protein aggregation is immunogenicity, which may result from the multiplicity of epitope and/or change in conformation $[82,83]$. Immunogenicity refers to antibody formation by the indigenous immune system against the administered biologics. Antibodies formed can be neutralizing in nature and thus may simply result in the loss of efficacy of the administered therapeutic. If the level of neutralizing antibody is very high, it may result in the neutralization of the essential endongenous protein; for example, the neutralization of endogenous erythropoietin by the antibody, formed against recombinant human erythropoietin (epoetin), has been reported to cause red cell aplasia [84]. 
Examples of IFN- $\beta-1 b$ and erythropoietin have been included here to provide an analogy for $\mathrm{mAb}$ degradation and its possible effect on immunogenicity and biological activity, since degradation of proteins (in general) and their biological consequences follow a similar pattern. Specific example of mAb degradation (aggregation) and induction of immune response can be found in a recent article published by Joubert et al. [85]. In this article the author has clearly shown that presence of large number of particles in therapeutic mAb formulation to induce immunogenicity through innate immune response, which may further progress through T-cell response [85].

Aggregation of naturally occurring immunoglobulin into fibrillar or amorphous type of aggregates, followed by deposition inside the glomeruli, is known to cause renal failure [86]. Since aggregation is commonly observed with therapeutic immunoglobulin, there is a chance of potential toxicity. Thus, aggregation is a major issue in the development of biopharmaceuticals and requires careful characterization and quantification. Level of aggregates in clinical and commercial drug product is tightly controlled by the regulatory agencies $[48,51]$. The amount of sub-visible particles allowed in a commercial product is governed by USP $\langle 788>$, which states that the amount should not exceed 6,000 particles for $\geq 10 \mu \mathrm{m}$ size and 600 particles for $\geq 25 \mu \mathrm{m}$ size, per container of nominal volume $\leq 100 \mathrm{~mL}$ [87]. Level of soluble aggregates in commercial product is required to be less than $5 \%$, according to WHO standards [16]. On the other hand, injectable biologics are required to be free of visible particles and $100 \%$ visual inspection is required for releasing clinical and commercial products [51]. Besides aggregation, chemical degradation may also lead to the loss in the activity of biologics; for example, isomerized species of Herceptin ${ }^{\circledR} \mathrm{mAb}$ (isomerization on Asp in CDR) was found to posses only $9-21 \%$ of biological activity of the native species [88]. Oxidation, on the other hand, may result in enhanced immunogenicity [82]. In fact, the oxidized form of rh-IFN 22 a was reported to show increased immunogenicity compared to its non-oxidized form [89].

\subsubsection{Stabilization Approaches}

A thorough understanding of the mechanism, by which biopharmaceuticals degrade, has enabled the pharmaceutical scientists to propose various stabilization strategies. Some of these stabilization strategies will be briefly discussed in this section, with the primary focus on liquid formulation.

The first step in formulation development is $\mathrm{pH}$ optimization. The most common approach is to identify the $\mathrm{pI}$ of the mAb from the primary sequence, typically using a commonly available software such as ExPASy or Sednterp [90], followed by formulation of $\mathrm{mAb}$ at $\mathrm{pH}$ away from the pI. However, it is important to perform an assessment of the target $\mathrm{pH}$, at which the molecule is adequately stable. $\mathrm{pH}$ has been reported to have an effect on conformational stability [91]. $\mathrm{pH}$ can alter the ionization behavior of the charged amino acid group covering the protein surface, and thus may interfere with the favorable electrostatic interaction (e.g., salt bridge) required for maintenance of the native, folded structure [92]. As described in the previous section, various pathways of chemical degradation are $\mathrm{pH}$ sensitive. For example, deamidation and isomerization are favored at neutral and basic $\mathrm{pH}[14,67]$, thus it is preferable to formulate biopharmaceuticals at slightly acidic $\mathrm{pH}$. In fact, out of 28 commercially approved mAb-type biopharmaceuticals, 20 are formulated at $\mathrm{pH} \leq 6.5$ (data acquired through PharmaCircle [93]). The stability of mAb against CD20, which was reported to be oxidation sensitive at $\mathrm{pH} 7.5$, has been improved by lowering the $\mathrm{pH}$ to $5.0[94,95]$. A case by case optimization 
may be required for $\mathrm{pH}$-mediated stabilization against oxidation, as there are examples in which increase in $\mathrm{pH}$ was found to be stabilizing [95].

Besides $\mathrm{pH}$, buffer components also play an important role in stabilizing mAbs. Sodium phosphate and histidine are the most commonly-used buffer components in commercial formulations. While sodium phosphate is more common for low concentration $\mathrm{mAb}$ formulations $(\leq 10 \mathrm{mg} / \mathrm{mL})$, histidine is the primary buffer of choice for higher mAb concentrations [96]. Histidine has a pKa of $\sim 6$, which allows the preparation of mAb formulation under slightly acidic $\mathrm{pH}$ [96]. Moreover, histidine has been reported to demonstrate stabilizing effects [97,98], although contradictory findings have also been documented [94]. Nevertheless, histidine buffer has been found to be extremely useful in formulating several mAb-based commercial products and is suggested to be the primary buffer of choice [96].

Surfactants are also included in typical mAb formulations [96]. Surfactants are surface active agents that are amphipathic in nature (polar head and hydrophobic tail). Surfactants tend to accumulate at various interfaces, resulting in reduced interfacial tension. Interface can be air-water, ice-water, or solid-water (e.g., surface of the container and the liquid). Protein molecules are also surface active and tend to partition at the interface; complex three dimensional fold of polypeptide chains creates hydrophobic as well as charged (polar) patches along the surface, which provides proteins with amphiphilicity, the essential property of surface activity [99]. Surfactants may stabilize protein molecules from interfacial stress by preferentially accumulating at the interface, thus preventing the proteins from being partitioned onto the interface $[16,47,100]$. This loss can be significant, particularly in cases for formulations containing low protein concentration. Surfactants have also been reported to directly interact with the protein and prevent it from interfacial stress. Detailed description of the various surfactant mechanisms has been discussed in detail by Lee et al. [100]. Polysorbates (polysorbate-20 and -80) are the most commonly used surfactants in the pharmaceutical industry [101]. Out of 28 commercially approved pure mAb-type biopharmaceuticals, 24 contain either polysorbate20 or polysorbate-80 (data acquired from PharmaCircle [93]). Inclusion of polysorbate in biopharmaceutical formulation has been suggested to be a part of a platform formulation approach [96].

Another important constituent of biopharmaceutical formulation is a stabilizer. Stabilizers are typically small molecular entities and are added to the biopharmaceutical formulation based on the intended purpose. For example, stabilizers can be used as anti-oxidant, metal chelator, or cryoprotectant. For the protein of interest, careful assessment of possible degradation pathways must be conducted prior to selecting a stabilizer. Sugars and polyols are common stabilizers used as a cryoprotectant and/or bulking agent, of which, sucrose and trehalose are the two most widely used. The presence of cryoprotectants, such as sucrose and trehalose, may provide protection against freeze/thaw-induced degradation of drug substance which may undergo multiple freeze/thaw cycles during storage [94,102,103]. Polyols, such as mannitol and sorbitol, are commonly used as bulking agent during lyophilization. Sugars and polyols are also known to stabilize the protein conformation; analytically, this is represented by an increase in the protein unfolding temperature $\left(\mathrm{T}_{\mathrm{m}}\right)$. For example, sucrose was found to increase the $\mathrm{T}_{\mathrm{m}}$ of RNAse by about $10{ }^{\circ} \mathrm{C}$ [104]. Sugars and polyols have also been reported to stabilize proteins from chemical degradation. For example, the presence of mannitol or trehalose was found to increase the chemical stability of rhu anti-CD20 (recombinant human antiCD20) mAb by minimizing the amount of acidic species [94]. Li et al. [105,106] demonstrated that different types of sugars and polyols, such as glucose and mannitol, stabilize the hu-relaxin protein 
from metal-induced oxidation. For example, mannitol was found to stabilize rhu HER2 mAb from oxidation at the methionine residue [95]. For stabilization against oxidation, methionine is typically the stabilizer of choice [95]. Metal ion-induced oxidation is prevented by the addition of a chelator type of molecule, such as EDTA. Although EDTA is effective for most metal ions, there are certain metal ions, such $\mathrm{Fe}^{3+}$, for which EDTA has been found to be ineffective at preventing metal-induced oxidation [107]. Use of salt as stabilizer in biopharmaceutical formulation is a variable. Salts are known to influence the solubility and conformational stability of proteins, and their effect is concentration dependent [108]. At high concentrations, the effect on solubility and conformational stability has been proposed to follow the Hoffmeister series [109]. For both cations and anions, the stabilizing effect has been reported to increase as one moves from left to right in the series. On the other hand, increase in salt concentration (thus ionic strength) is known to screen charge-charge interactions, and thus decrease the proximity energy. Decrease in proximity energy has been proposed to be the cause of colloidal instability, and thus increase in aggregation [110]. Therefore, the use of salt as a potential stabilizer of biopharmaceuticals requires careful assessment.

\section{Development of High Concentration Formulation}

\subsection{Subcutaneous Delivery and Its Limitation}

Although mAb-based therapy was introduced primarily for the treatment of cancer, mAbs are reported to penetrate solid tumors poorly; in fact, only about $0.01 \%$ of the applied dose has been reported to penetrate into the tumor $[111,112]$. $\mathrm{EC}_{50}$ values are typically higher than those of globular proteins, such as cytokines [113]. Thus, there is a need for high dose delivery of mAbs.

High dose administration is made possible through intravenous (iv) infusion, however this often requires special set up and involvement of a health care provider. Although most of the commercial antibodies are administered via the iv route, there is an increasing trend towards the development of dosage forms for alternative routes of administration, in particular the subcutaneous (sc) route. For chronic diseases, such as asthma and arthritis, for which frequent administration is required, development of sc dosage form is valuable in many ways. This includes: ease of administration, patient compliance, and reduction in cost as administration is possible at home. One inherent limitation of sc dosage form is the injection volume. The maximum volume that can be administered is typically less than $2 \mathrm{~mL}$ [114]. The area available in the skin, under epidermis and dermis, is limited in such a way that injection of large volume creates high back pressure. Pain at injection site is another problem that is caused by a number of different factors such as individual expertise, needle size, and formulation [115]. It is also protein specific. Formulation plays an important role in controlling the pain at injection site. For example, histidine buffer is known to be less prone to cause pain upon injection compared to phosphate and citrate buffer [116-118]. Since mAbs are administered at high dose and the maximum injection volume is limited for sc delivery, development of stable and robust high concentration formulation is critical to enable sc administration of biopharmaceuticals. 


\subsection{Challenges of High Concentration Formulation Development}

High concentration is defined by the solution, in which a significant portion of the solution volume $(\geq 0.1)$ is occupied by the solutes $[119,120]$. Another definition of high concentration solution is the situation in which the molecular size and the distance between the Van der Waals surfaces are on the same order of magnitude [110]. Irrespective of the definition, high concentration refers to intermolecular distance or molecular proximity. The primary challenge in achieving high concentration formulation is the solubility of the target protein. Solubility is controlled by its molecular property (sequence, charge distribution, etc.), as well as by the solution condition, such as $\mathrm{pH}$, ionic strength, excipient concentration, etc. [121]. Solubility of a protein is defined by the maximum amount of the protein that can be present in a solution, without appearance of any visible aggregates, precipitates, etc. A more technical definition will be the maximum amount of protein that remains in solution, following $30 \mathrm{~min}$ of centrifugation at 30,000 $\mathrm{g}$ in the presence of co-solute $[122,123]$. Besides solubility, there are other issues associated with the development of high concentration mAb formulation. These include opalescence, viscosity, and aggregation. Opalescence is commonly expressed by nephelometric turbidity unit, however opalescence is not necessarily equivalent to turbidity. Typically a solution becomes turbid due to the presence of particulates. However, opalescence may result even if the solution is free of any particulates. Sukumar et al. [124] reported that an IgG1, demonstrating considerable opalescence at high concentration, was essentially monomeric, and the opalescence was primarily a result of Raleigh scattering. Although opalescence is not a major issue, and may occur independent of aggregation, it remains a major concern as it may fail to satisfy patient compliance due to its appearance. Reversible protein-protein and liquid-liquid phase separation may also lead to opalescence [124,125]. Proteinprotein interaction at high concentration is a major factor that may influence opalescence and viscosity. When molecules are in close proximity, they can interact with each other, resulting in reversible self-association, increase in viscosity, opalescence, and even aggregation [126]. Protein-protein interaction has been explained by various theories, including molecular crowding, or excluded volume effect, and proximity energy effect, etc. [110,127].

Increase in viscosity at high concentration has a major impact on manufacturability and injectability. Tangential flow filtration (TFF) is one of the main technologies used for buffer exchange and concentrating proteins during large scale manufacture (clinical as well as commercial) [128]. Increase in viscosity at high concentration may create back pressure high enough to exceed the capacity of the pump. TFF process itself is considerably stressful to the mAb, as rapid pumping and continuous circulation through the narrow tubing create significant cavitation and shear stress [129]. Increase in back pressure, due to increase in viscosity, may retard the process further which can be even more destabilizing to the protein. At minimum, this increases the process time, and in turn, the cost of manufacture. Increase in viscosity has a significant impact on administration of sc dosage form. Ease of sc injection is described by the glide force, or extrusion force, which refers to the force required to push the liquid through the syringe. While there are various factors including needle gauge, length of needle, etc., that are associated with glide force, one of the main contributing factors is solution viscosity. Viscosity has been reported to be directly correlated to glide force for sc injection [130,131]. Increase in viscosity increases the time of injection, and also the pain at injection site, which may lead to decrease in patient compliance [132]. 
Protein-protein interaction in a high concentration formulation may result in reversible self-association, which may further progress towards the formation of insoluble aggregates. At high concentration, the probability of one molecule bumping into another is much higher, and this increases the chances of formation of reversible oligomers such as dimer, tetramers, etc. Formation of aggregates occurs through multiple mechanisms, including the formation of covalent linkages (e.g., disulfide exchange). Even minor conformational change in the native structure may lead to the formation of aggregates. At high concentration, the probability of such occurrence is greater than that in a dilute solution [126].

\subsection{Analytical Assessment of High Concentration Formulation}

Most of the analytical techniques employed for the assessment of chemical degradation of $\mathrm{mAb}$ in a dilute solution (e.g., ion exchange chromatography, capillary gel electrophoresis, reversed phase chromatography, mass spectrometry, etc.) can be utilized for high concentration formulation. The primary challenge around adapting these techniques for high concentration formulation is sample preparation, which typically involves dilution of the concentrated stock. Since chemical degradation is relatively less sensitive to concentration, adaptation of these techniques for high concentration formulation is relatively straight forward [129]. On the other hand, the assessment of aggregation and particle formation (physical degradation) is much more complicated as dilution of test sample is not the most suitable option, because it may modulate specific high concentration behaviors, such as reversible self association. Direct measurement of molecular property at high concentration is extremely challenging due to thermodynamic non-ideality and high viscosity associated with high concentration [126]. Only a few techniques can be utilized for the direct assessment of high concentration formulation. These include preparative analytical ultracentrifugation (AUC), fluorescence detection system (FDS) equipped with AUC, membrane osmometry, and static light scattering, to some extent [129]. With preparative AUC, samples at high concentration are sedimented under equilibrium mode, and the content of the centrifugation tube is collected in fractions using an automated microfractionator, followed by measurement of protein concentration using UV spectroscopy [133,134]. This method is time consuming, labor intensive, and the number of data points collected is typically one-third of what is collected from a regular AUC [129]. Availability of FDS allows measurement of sedimentation behavior directly in the AUC instrument. This technique requires the fluorescent labeling of the target $\mathrm{mAb}$, however. Labeled $\mathrm{mAb}$ is added to the unlabeled high concentration formulation to serve as a tracer molecule. Since the fluorescently-labeled $\mathrm{mAb}$ is present only at trace quantity and is structurally and functionally indistinguishable from the unlabeled mAb, it is expected that the labeled $\mathrm{mAb}$ will be part of the reaction kinetics and intermolecular interaction occurring under the high concentration condition. Thus it is extremely important to ensure that both structural and functional integrity have not been compromised by labeling of the molecule $[135,136]$. There are examples in which static light scattering (SLS) has been utilized for assessing the aggregation behavior of a protein at high concentration, however, the consequence of multiple scattering at higher concentration should be carefully evaluated [137]. Membrane osmometry has been utilized to measure the osmotic pressure of high concentration formulation. At high concentration, for which considerable thermodynamic non-ideality exists (due to self-association and molecular crowding), concentration 
gradient of osmotic pressure deviate from linearity and demonstrates concentration dependence [138]. Yousef et al. [139] measured the osmotic pressure of bovine IgG solution up to $424 \mathrm{mg} / \mathrm{mL}$. Mathematical interpretation of the self-association behavior from concentration dependence of osmotic pressure data is difficult. Various models have been utilized to interpret osmotic pressure data, such as the free solvent model, leading to reversible association and non-ideal behavior [133,139].

Since the assessment of molecular behavior directly at high concentration is challenging, some alternative approaches have been proposed that utilize dilute solution properties to predict and represent high concentration behavior. Most commonly used dilute solution parameters are second virial coefficient (B22), diffusion interaction parameter (Kd), and net charge. Second virial coefficient is a measure of intermolecular interaction, and is primarily driven by electrostatic attraction or repulsion, van der Waals attraction, and repulsion from molecular crowding [140-142]. Positive and negative B22 in general refer to repulsive and attractive interactions, respectively [141]. For example, Saito et al. [143], found that the B22 value, measured by sedimentation equilibrium, demonstrated strong qualitative correlation with the viscosity and aggregation propensity of mAbs. There are different ways by which B22 value can be measured, including the composition gradient SLS, self interaction chromatography (SIC), osmometry, etc. [144-150]. Diffusion interaction parameter (Kd) is another useful, dilute solution property that can be utilized for the prediction of high concentration behavior. $\mathrm{Kd}$ is expressed by the slope of the linear relationship of diffusion coefficient $v s$. concentration, and can be determined by dynamic light scattering in a high-throughput manner [151]. $\mathrm{Kd}$ is related to B22 via an equation developed by Harding and Johnson [152], and thus can be utilized for indirect measurement of $\mathrm{B} 22 . \mathrm{Kd}$ can be directly correlated to the viscosity and aggregation propensity of high concentration mAb solution, as reported by Connolly et al. [153]. On the other hand, the net charge on protein molecule plays an important role in determining the proximity energy when the intermolecular distance is $<1 \mathrm{~nm}$. Charge-charge interaction is repulsive in nature and increases the proximity energy. Increase in proximity energy relates to increase in activation energy barrier that needs to be overcome while two molecules are interacting with each other [110]. Thus, high charge is preferable for lowering viscosity (reduced reversible self association) and minimizing aggregation. Moreover charge measured at dilute solution is expected to be least influenced by concentration, given that the structural property of the molecule and the solution property remain unchanged [110]. A number of methods are available for the measurement of net charge. Most of these techniques utilize the principle of electrophoretic mobility; e.g., capillary zone electrophoresis (CZE), membrane confined electrophoresis (MCE) [154,155], and a new technique from Wyatt tech corporation that utilizes massively parallel phase analysis light scattering (MP-PALS) [156]. Although the above mentioned parameters are measured to predict high concentration behavior, there is another school of thought that claims prediction of high concentration behavior from dilute solution is not reliable [133,157].

\section{ADC}

The rapid growth in monoclonal antibody $(\mathrm{mAb})$ therapeutics has recently stimulated the research and development of antibody-drug conjugates (ADCs) in different phases [158-160]. The key drive for the development of ADCs was to make use of the binding specificity of the antibodies for cell surfaceassociated antigens to bring the cytotoxic agents (small molecular drugs or toxins) to the desired cell 
population. Specific binding of ADCs to cell surface-associated antigens would minimize the nonspecific and intolerable effects of cytotoxic agents on normal cells. The binding of ADCs to specific tumor-associated antigens (TAAs) can trigger internalization of the binding complex and release the drugs inside the cancer cells for the intended cytotoxic action [161]. In addition, the released small molecule drugs, due to its membrane permeability, are able to exert cytotoxic activity on bystander cells [162].

Another reason for the development of ADCs is to address the issue of drug resistance. It is known that P-glycoprotein (P-gp), a drug transporter, is abundantly expressed in tumors and facilitates the elimination of chemotherapeutics, a phenomenon known as multidrug resistance (MDR) [163]. Drug resistance has been observed both for anticancer small molecule drugs [164,165] and mAbs [166,167]. The concept of ADCs as magic bullets was proposed decades ago [168], however only three such drug products have been approved in the US; gemtuzumab (anti-CD33) ozogamicin (Mylotarg®) for acute myeloid leukemia (AML) in 2000 (voluntarily withdrawn from the US market in 2010), brentuximab (anti-CD30) vedotin (Adcetris $\left.{ }^{\circledR}\right)$ in 2011 for Hodgkin's lymphoma or anaplastic large cell lymphoma, and ado-trastuzumab (anti-HER2) emtansine (Kadcyla $\left.{ }^{\circledR}\right)$ for HER2-positive metastatic breast cancer in early 2013. The limited number of ADC approvals is due, in part, to two significant challenges: (1) inadequate cellular uptake (likely $<1 \%$ ); and (2) residual off-target effects. To address the first issue, the antibody needs to be designed to target one or more surface antigens with high binding affinity and high rate of internalization. The antibody target should be highly, or overly, expressed in the target cells [169]. It is also necessary to use cytotoxic agents, which are highly effective at low concentrations, with a clear mechanism of action. The second issue is discussed in the following section.

\subsection{Design and Selection of Different Linkers}

One of the main reasons for off-target effects is the premature release of drugs outside of target cells. The premature release explains the faster-than-expected clearance of the conjugates of cantuzumab mertansine (huC242-DM1) in blood [170]. On the other hand, the drugs need to be readily releasable inside the cells to exert their cytotoxic effects. This requires a delicate balance in designing chemical linkers that possess high stability in the bloodstream, while allowing efficient payload release within the target cells. Various types of chemical linkers have been designed to achieve the desired properties $[171,172]$.

The traditional linking sites in the preparation of protein conjugates are primary amines on lysines. The $\varepsilon$-amino group in lysine residue can be easily acylated. However, depending on the number and relative accessibility of lysine residues on the protein surface, the random acylation process would generally result in a heterogeneous mixture of conjugates. Mylotarg ${ }^{\circledR}$ (gemtuzumab ozogamicin), the first-generation $\mathrm{ADC}$, is a heterogeneous mixture of $50 \%$ unconjugated antibody and $50 \%$ conjugated antibody with 1 to 8 calicheamicin moieties per IgG molecule (average of 2-3 drug molecules), randomly linked to solvent-exposed lysyl residues of the antibody [169]. The heterogeneity of the drug product requires stringent process controls to achieve product consistency, and characterization of the product mixture is a significant burden for analytical/quality control.

These challenges have led to the use of thiols for mAb conjugation, as the number of thios is limited and fixed in the different subtypes of IgGs. The commercial antibody products are primarily IgG1s, 
which possess 4 inter- and 12 intra-chain disulfide bonds. Drugs can be linked to inter-chain disulfides following reduction [173]. Nonetheless, the use of disulfides for conjugation may still yield a heterogeneous population of conjugated products that contains positional isomers [174]. The heterogeneity derives from the different tendencies of disulfides for reduction during the conjugation process. Using two mAbs as model proteins, it was found that: (1) the inter-chain disulfide bonds are more susceptible to reduction than intra-chain disulfide bonds; (2) the disulfide bonds between the light and heavy chains are more susceptible than disulfide bonds linking two heavy chains; (3) the upper disulfide bonds linking the two inter heavy chains are more susceptible than the lower one, and (4) disulfide bonds in the $\mathrm{CH} 2$ domain are the most susceptible to reduction [175]. Heterogeneity can be minimized by preferential cleavage of particular $\mathrm{mAb}$ inter-chain disulfides through chemical reduction and oxidation, and isomeric homogeneity can be as high as 60-90\% [176]. Another obvious option to minimize heterogeneity is to create a limited number of cyteine residues through engineering $[177,178]$. Indeed, much more homogeneous conjugates have been obtained through this process [178]. On the other hand, the engineering sites need to be carefully chosen to not affect the original activity of mAb and the conjugates. The solvent accessibility and spatial environment of the engineering sites have been demonstrated to influence the stability of thiol-reactive linkers and therapeutic activity [179]. Minimization of conjugate heterogeneity can also be achieved through engineering unnatural amino acids and precise control of the conjugation site and stoichiometry. For example, p-acetylphenylalanine was site-specifically incorporated into both a Fab fragment and full-length $\mathrm{IgG}$, and conjugated to an auristatin derivative through a stable oxime linkage [180].

A commonly-used conjugation chemistry is the reaction between $-\mathrm{SH}$ and maleimide functional group, leading to the formation of cleavable thiosuccinimide in the presence of excessive thios. Several issues with this approach exist, however. First, the thioether bond formed by the reaction is unstable. It can undergo hydrolysis in dilute solutions, as demonstrated for immunoconjugates formed by the maleimide-sulfhydryl method [181]. The drug can be released in human plasma from thioether linked ADCs through sulfoxide formation and elimination [182]. Second, the ring structure is not stable and the thioether-maleimide has been reported to undergo complete hydrolysis of the maleimide ring (ring opening reaction) at $\mathrm{pH} 8$ in $4 \mathrm{~h}$ at $37^{\circ} \mathrm{C}$ [183].

These issues, along with the challenge in balancing the stability in blood and cleavability within the target cells, led to the design of many other different types of cleavable linkers, such as dipeptide linkers; valine-citrulline [184], Val-Cit, and Phe-Lys [185]. The limited in vivo stability of cleavable linkers in plasma led to the design and testing of non-cleavable leakers, which are generally more stable, such as maleimidocaproyl linker [186]. Presumably, due to the increased stability of the linker, reduced toxicity was observed relative to conjugates with cleavable linkers [187]. If the linkers are non-cleavable, release of the drug has to occur through degradation of the antibody protein in the lysosome, and the linker-retained drug needs to be active. Indeed, ADCs can be adequately processed to release the active form of the drug in the lysosomes of the target cells, such as mAb-maytansinoid conjugates containing either a disulfide linker or a thioether linker [188]. The superior efficacy and reduced toxicity of a trastuzumab-maytansinoid (mAb-DM1) conjugate eventually led to the approval of T-DM1 this year as the first ADC with a non-reducible thioether linker, following demonstration of both safety and efficacy [167]. 


\subsection{Optimization of Antibody Drug Ratio}

Another issue in the preparation of ADCs is to optimize drug load, or the antibody-drug ratio (ADR). Ideally, the affinity of the conjugated antibody for its target should not to be affected relative to the naked antibody. In general, the greater the number of drug molecules loaded onto an antibody, the higher the plasma clearance, and the weaker the binding strength between the antibody and antigen. Increasing the drug load may not increase the efficacy after reaching a limit [173,189].

\subsection{Formulation Challenges}

As discussed above, ADCs contain three components: mAb, linker, and drug. Among the three components, mAb and linkers are the first to be considered for formulation stabilization, as they are generally less stable than the small molecule drugs.

mAbs generally have reasonable stability, and approximately half of all naked mAb drug products are in liquid dosage form. Their stability can be negatively impacted during and/or following chemical modification for ADCs. Many of the small drug candidates are relatively hydrophobic, such as calicheamicin and paclitaxel, and the addition of a hydrophobic group would enhance the hydrophobicity-driven aggregation tendency. In addition, conjugation via lysine residues may lead to the reduction in the number of protein surface charges and the hydrophilicity of the protein. Thus, the addition of such molecules to antibodies may negatively impact antibody stability [190,191] or solubility [192].

Some peptide linkers are relatively hydrophobic and can negatively influence the stability of ADCs. In the preparation of a mAb and doxorubicin conjugate using Phe-Lys or Val-Cit as a linker, the formation of non-covalent dimer was observed immediately upon conjugation [185]. In another example, the addition of a hydrophilic methoxytriethylene glycol chain onto doxorubicin, via a hydrazone bond, has been reported to greatly inhibit the aggregation of final conjugates, most likely due to the hydrophobic nature of these peptides [193].

Ideally, the linkers are stable enough to prevent the generation of any amount of free cytotoxic drugs during formulation, manufacturing process, shipping, and storage. The reality is that most cleavable linkers discussed above possess limited in vitro stability. For example, the conjugate vaccine amAb-KLH, linked via succinimidyl 4-( $N$-maleimidomethyl)-cyclohexane-1-carboxylate (SMCC), is stable in PBS (pH 7.2) only at $-80{ }^{\circ} \mathrm{C}$, and significant release of free mAb was observed at $4{ }^{\circ} \mathrm{C}$ over 6 months of storage [194]. In addition, the linker stability can be significantly influenced by the neighboring groups [195].

Thioether oxidation was implicated in linker instability and varying rate of oxidation was observed at different $\mathrm{pH}$ 's [182]. These examples demonstrate that the solution $\mathrm{pH}$ of ADCs is a critical parameter for evaluation in the development of a stable formulation. Lyophilization may have to be used if the linker instability is difficult to control. In fact, all three commercial ADC products are in lyophilized form (Table 2). 
Table 2. Information on currently available commercial antibody drug conjugates (ADCs).

\begin{tabular}{|c|c|c|c|c|c|c|}
\hline ADC & Linker & $\begin{array}{c}\text { Drug- } \\
\text { antibody } \\
\text { ratio (DAR) }\end{array}$ & $\begin{array}{l}\text { Dosage } \\
\text { form }\end{array}$ & Excipients & $\begin{array}{c}\text { Package } \\
\text { system }\end{array}$ & $\begin{array}{c}\text { Product } \\
\text { storage }\end{array}$ \\
\hline $\begin{array}{c}\text { Mylotarg® } \\
\text { (withdrawn in } \\
\text { 2010) }\end{array}$ & $\begin{array}{c}N-4-(4- \\
\text { acetylphenoxy) } \\
\text { butanoic acid and } \\
N \text {-acetyl- } \gamma \text { - } \\
\text { calicheamicin } \\
\text { dimethl hydrazide }\end{array}$ & $2-3$ & Lyo & $\begin{array}{c}\text { Dextran } \\
40, \\
\text { sucrose, } \\
\mathrm{NaCl} \text { and } \\
\text { phosphate } \\
\text { buffer }\end{array}$ & $\begin{array}{l}\text { Single- } \\
\text { use } \\
\text { amber } \\
\text { glass }\end{array}$ & $2-8^{\circ} \mathrm{C}$ \\
\hline $\begin{array}{c}\text { Adcetris }{ }^{\circledR} \\
\text { (approved in } \\
\text { 2011) }\end{array}$ & $\begin{array}{l}\text { Maleimidocaproyl } \\
\text {-valine-citrulline }\end{array}$ & $\sim 4$ & Lyo & $\begin{array}{c}\text { Trehalose, } \\
\text { polysorbat } \\
\text { e } 80, \text { and } \\
\text { citrate } \\
\text { buffer }\end{array}$ & $\begin{array}{l}\text { Single- } \\
\text { use glass } \\
\text { vials }\end{array}$ & $2-8^{\circ} \mathrm{C}$ \\
\hline $\begin{array}{c}\text { Kadcyla® } \\
\text { (approved in } \\
\text { 2013) }\end{array}$ & $\begin{array}{c}4-[N- \\
\text { maleimidomethyl] } \\
\text { cyclohexane-1- } \\
\text { carboxylate } \\
(\mathrm{MCC}) \\
\end{array}$ & $\sim 3.5$ & Lyo & $\begin{array}{l}\text { Sucrose, } \\
\text { polysorbat } \\
\text { e 20, and } \\
\text { sodium } \\
\text { succinate }\end{array}$ & $\begin{array}{l}\text { Single- } \\
\text { use glass } \\
\text { vial }\end{array}$ & $\begin{array}{c}2-8{ }^{\circ} \mathrm{C} \\
(4 \mathrm{~h} \text { limit } \\
\text { after recon } \\
\left.\text { at } 2-8{ }^{\circ} \mathrm{C}\right)\end{array}$ \\
\hline
\end{tabular}

\subsection{Challenges during Product Manufacturing and Stability Monitoring}

ADCs are complex drug products. Purified drug substance intermediates include mAbs, linkers, and small molecule drugs. Several reaction steps may have to be carefully controlled to manufacture drug products consistently. Due to the high toxicity of small molecule drugs, dedicated suites for handling these agents and ADCs may be required. Isolators may be ideal, however operation may not be efficient. Prevention of cross contamination and good cleaning procedures require implementation. Due to the stringent requirement for aseptic processing and specific handling requirement for the cytotoxic agents, manufacturing processes may need to take place in different phases at different manufacturing sites. This will certainly make the manufacturing process complex and time-consuming.

\section{Antibody Fusion Construct}

Fusion proteins are designed to possess multiple functions, i.e., site-specific delivery. The main difference between ADCs and fusion proteins is in the molecular structure. In ADCs, toxic agents are chemically conjugated to antibodies or their fragments, as depicted in Figure 1, while for fusion proteins, effector molecules (either protein or peptide) are inserted into the protein on the genetic level. Here, fusion proteins are grouped into three distinct classes depending on the mode of construct. First class (Figure 1) is composed of mAb (or fragments) and effector molecule. Fc-fusion proteins are composed of binding/functional peptides or proteins fused to the Fc-domain [12] (Figure 1). While antibody (or fragment) fusion proteins utilize specific antigen binding property of antibodies, Fc-fusions lack antigen-binding variable domains, and thus are not designed for targeted delivery. The Fc-domains are fused to either enhance the circulating half-life or confer ADCC or CDC function. Although no formal distinction exists, Fc-fusion proteins may be formally divided into Fc-protein fusion and Fc-peptide fusion. 
Figure 1. Illustrative comparison of the structure of ADC to those of fusion proteins. Note that although these effector molecules are shown to be fused to either the $\mathrm{N}$ - or C-terminus, they can also be fused to the other terminus. Though ADCs are shown to be linked to the C-terminus of antibodies or their fragments, they can also be linked to other functional groups, e.g., the $\mathrm{N}$-terminus or side chains, by in vitro chemical reaction.

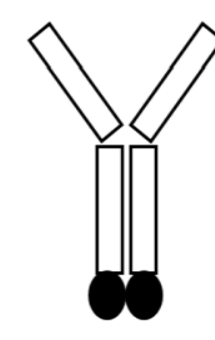

$\mathrm{ADC}$

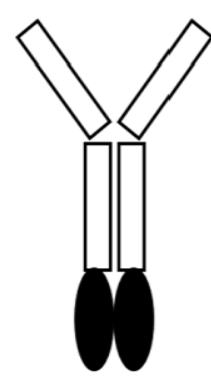

Payload

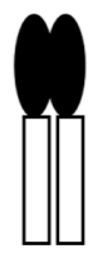

Fc fusion

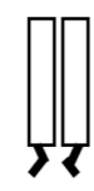

Peptibody

\section{1. mAb-Effector Fusion Protein (Payload)}

Antibodies and their fragments can be fused to various effector molecules, e.g., enzymes, toxic proteins, cytokines, and other functional proteins, on either the $\mathrm{N}$ - or $\mathrm{C}$-terminal. In some cases, antibodies directed at tumor-associated antigens are fused to enzymes for specific delivery to tumor cells, in which the enzyme cleaves the prodrug (which has been administered separately), and penetrate the tumor cell as a cytotoxic drug (Figure 2). While the prodrug may also penetrate healthy cells, it cannot be converted to a cytotoxic form, and thus is not toxic [196]. Similar to ADCs, immunotoxins are fusion proteins designed for the targeted delivery of toxic agents. Plant or bacterial toxins are genetically fused to antibodies or their fragments and delivered to cancer cells, in which the fusion proteins are internalized and subsequently kill cancer cells [197]. Enzymes, such as ribonuclease (RNase) and granzyme B (granule-derived serine protease), can be used as a cytotoxic agent of immunotoxins [198-201]. RNase and granzyme B have been delivered to various cancers through different tumor antigens (e.g., CD22, CD32, CD64, HER2, mucin, and MEL) using specific antibodies or their fragments (e.g., scFv) [202].

Figure 2. Illustration of the mechanism of mAb-effector fusion protein of a prodrug. The $\mathrm{mAb}$ is directed towards tumor-associated antigens and the enzyme is delivered to the tumor cell, within which the prodrug is cleaved, releasing the cytotoxic drug.

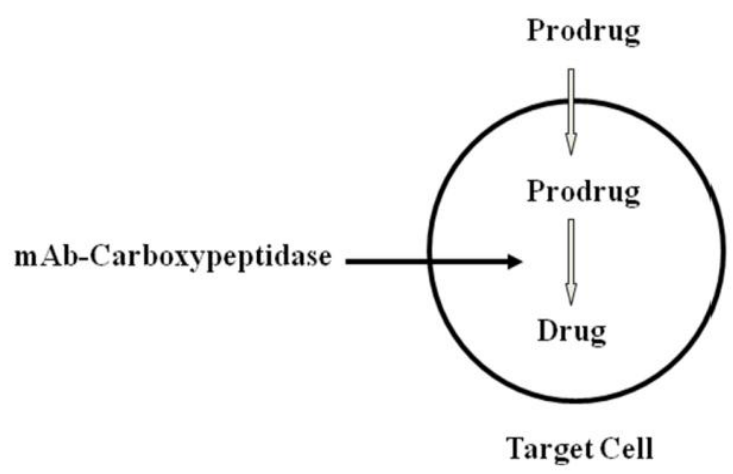


Another interesting construct is a mAb/avidin fusion construct. Tumor-specific delivery of cell death factors possess great potential as anti-cancer fusion proteins [202]. Although it is in itself not an antibody-effector fusion protein, it can deliver toxins site-specifically into tumors for biotin-labeled compounds. If toxins are small molecule drugs, the fusion is essentially the same as in ADC. In this case, the fusion construct is based on an antibody (or its fragment) fused to avidin. One example is anti-transferrin fusion of avidin. Transferrin plays a pivotal role in iron uptake, and transferrin receptor (TfR) has been reported to be more abundantly expressed in dividing cells [203]. Anti-TfR antibody can thus target cancer cells. In addition, TfR is expressed in blood-brain barrier and can be targeted by the same antibody or fragments [204]. In fact, neurotrophic nerve growth factor was delivered to the brain by conjugating the factor to anti-TfR antibody [205,206]. Anti-TfR antibody can thus be used for the delivery of effector proteins to the brain. Fusion process of the effector molecules can be bypassed by constructing anti-TfR fusion with avidin, as long as biotinylated effector molecules are readily generated. Avidin is a non-covalent tetramer. The covalent structure of the anti-TfR antibody/avidin fusion was found to contain two avidin molecules, as expected in a dimeric fusion molecule (see Figure 3). Size exclusion chromatography analysis demonstrated, however, a molecular weight of $400 \mathrm{kDa}$ for the fusion, suggesting that this fusion is a non-covalent dimer. This is most likely due to the formation of tetrameric avidin complexes that bring two antibodies together, as depicted in Figure 3 [207]. Brain uptake of biotinylated anti-sense PNA (peptide-nucleic acid) against HIV was greatly enhanced when co-administered with the anti-TfR/avidin fusion protein [207].

Figure 3. Illustration of a tetrameric fusion complex (anti-transferrin receptor (TfR) antibody/avidin fusion). Avidin ( $\mathrm{O}$ ) is fused to the C-terminus of the antibody.

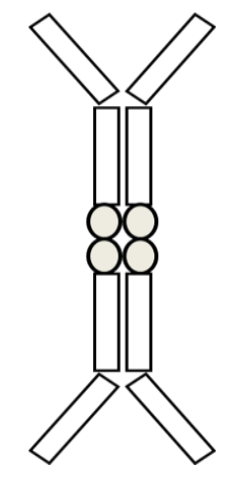

TfR can also be used for the delivery of therapeutics into cancer cells as described above. The anti-TfR antibody/avidin fusion has been reported to deliver biotinylated glucose oxidase (MW 18.6 kDa), and even a larger protein, into cancer cells [208]. Although this construct was developed for delivery through TfR, it was accidentally observed to induce apoptosis in cancer cells [208]. It appears that both the anti-TfR antibody and avidin moieties are required to exert such apoptotic effects.

Anti-CD20 mAb (Rituxan $\left.{ }^{\circledR}\right)$ has been developed to treat B-cell non-Hodgkin lymphoma. To further improve its efficacy, a cytokine fusion protein was developed [209]. Interferon- $\alpha$ was used as an effector cytokine, as it inhibits cell proliferation and augments immune systems. This fusion was able to recruit interferon- $\alpha$ at tumor sites and significantly enhance the anti-tumor effects of Rituxan®.

Neuroblastoma highly expresses disialoganglioside $\left(\mathrm{GD}_{2}\right)$. A fusion protein comprising anti-GD $\mathrm{GD}_{2}$ $\mathrm{mAb}$ and IL2 (as a fusion) demonstrated anti-tumor responses in neuroblastoma patients [210]. This 
fusion construct has been reported to enhance the delivery of IL2 to tumor microenvironments and result in activation of natural killer cells, through IL2 binding to the cognate receptor, as well as tumor cell killing via ADCC mechanism [211,212].

HER2 is over expressed in certain breast cancer patients. Anti-HER2 mAb (Herceptin®) demonstrated regression of tumors, however only for some patients. GM-CSF is a cytokine that promotes growth and differentiation of granulocyte-macrophage lineages and stimulates immune responses. High local GM-SCF concentration at tumor sites should enhance its anti-tumor T-cell immunity. Thus, anti-HER2 GM-CSF fusion protein was constructed to recruit this cytokine to breast cancer cells [213]. The fusion protein was reported to bind to its antigen (cell-surface HER2) with the same affinity as for anti-HER2 mAb. Similarly, the fusion protein stimulated the cell line, whose proliferation depends on GM-CSF, at the same concentration as the free cytokine. This fusion protein exhibited tumor killing through both Fc-mediated ADCC and macrophage activation.

Endostatin demonstrates strong suppressive effects on angeogenesis and tumor growth, but demonstrated marginal therapeutic efficacy in clinical trials. Anti-HER2 IgG3 fusion of endostatin demonstrated a drastic improvement in serum half-life and stability, and increased the local endostatin concentration around HER2 expressing tumor [214].

Decay-accelerating factor (DAF) is an inhibitor of complement activation. This inhibitor was fused to the C-terminus of anti-dansyl mAb or its fragments [215]. This fusion protein bound both dansyl and anti-DAF antibody. CHO cells conjugated with dansyl were used to confirm cell surface binding of the anti-dansyl IgG/DAF fusion protein. The fusion protein has been reported to protect complement-mediated cell lysis.

\subsection{Protein-Fc Fusion}

This fusion construct makes no use of antibody's unique function, i.e., antigen specificity, as it lacks antigen binding variable domains. Variable domains are replaced with the protein of interest, which is fused to Fc for prolonging circulation life, CDC and ADCC, or dimerization. Fc also facilitates purification, as it specifically binds to Protein-A or Protein-G. The main difference from peptibodies, described next, is that the molecule to be fused is a protein or a domain of naturally existing proteins. Although each protein in the fusion construct may be readily folded, the fusion protein is a non-natural construct, particularly in the linker region, which may cause folding problems. A blockbuster product, etanercept (Enbrel $\left.{ }^{\circledR}\right)$, belongs to this group of constructs. It comprises tumor necrosis factor receptor (TNFR) fused to Fc. Mammalian expression of etanercept illustrates this folding problem. Two patents from Immunex report this folding problem when the fusion was derived from a mammalian expression system [216,217]. When Protein-A purified etanercept was analyzed by analytical hydrophobic interaction chromatography (HIC), three distinct peaks were typically observed. First peak corresponds to the clipped form, second peak to the native etanercept (N-etanercept), and the third peak (PIII) to the misfolded form. SDS-PAGE analysis of PIII mainly demonstrated the band of N-etanercept along with small amounts of aggregates and the clipped form. PIII demonstrated greatly reduced activity, perhaps reflecting its incorrect structure. Nevertheless, spectroscopic and peptide mapping analysess suggested that the misfolded structure is rather limited to 
the localized area, which involves SS pairing. More importantly, the amount of PIII in the culture media varied from $\sim 10$ to $\sim 60 \%$, depending on the fermentation conditions.

Glycosylation, in particular sialylation, can vary between different products, even if their amino acid sequences are identical. Although such difference does not appear to affect biological activity, it may alter the serum half-life, suggesting the importance of glycosylation on pharmacokinetics. At this moment, whether fusion of TNFR to Fc in etanercept affects glycosylation is unclear.

As in etanercept, the majority of Fc-protein fusions comprise an extracellular domain of receptors fused to the N-terminus of the Fc domain (Figure 4A). There are many applications of this type of construct. Triggering receptor expressed on myeloid cells (TREM-1), expressed on immune cells, is a TREM family member which is engaged in inflammation responses. TREM-1 can cause, upon bacterial infection, excessive amplification of inflammation and mediate septic shock [218]. The administration of TREM-1/Fc fusion has been reported to result in decreased septic shock [219] and improve disease symptom from collagen-induced arthritis, similar to etanercept. Similarly, anti-angeogenic vascular endothelial growth factor (VEGF) inhibitor has been developed as an Fc-fusion protein, termed VEGF-Trap [220]. It is a fusion protein containing VEGF receptor-1, VEGF receptor-2, and Fc domain of human IgG.

Hemophilia B results from a deficiency of factor IX (FIX), which is responsible for blood coagulation. Patients suffering from a bleeding disorder are treated by injection or infusion of FIX, whose short circulation life time often requires repeated treatments. Recombinant Fc fusion protein of FIX has been prepared by expressing together an FIX-Fc fusion gene and an Fc gene, resulting in FIX-Fc monomer comprising one functional FIX and two Fc domains (Figure 4B). This fusion construct demonstrated higher circulation half life, due to its binding to FcRn, and resultant recycling of the fusion molecule [221]. Factor VIII (FVIII) is also involved in the blood coagulation cascade. Hemophilia patients with low level of FVIII suffer a similar bleeding disorder. Recently, Biogen Idec filed a BLA for a longer circulating FVIII-Fc fusion protein.

Figure 4. Illustration of various Fc-fusion proteins: (A) construct of extracellular domain of receptors (ExR) fused to the N-terminus of Fc, (B) FIX (coagulation factor IX) - Fc monomer comprising one functional FIX and two Fc domains, and (C) Fc fusion of the peptide, romiplostin/Nplate ${ }^{\circ}$, that contains two tandem repeats of the peptide. $\mathrm{Fc}$ is depicted as long rectangles and the peptide as short rectangles. These three constructs form dimers through the Fc domain.

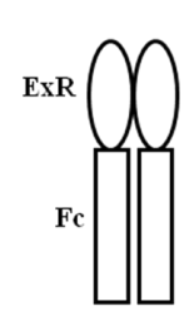

A

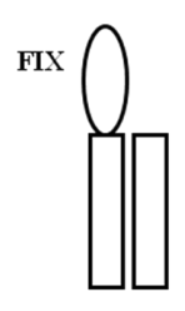

$\mathrm{B}$

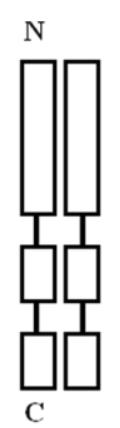

$\mathrm{C}$ 


\subsection{Peptibody}

Short peptides occupy a large portion of biopharmaceutical drugs currently available. Short peptides are significantly different from proteins in their structural properties; many short peptides are disordered, flexible, with a strong tendency for aggregation, unless structurally constrained. While a large number of short peptides are naturally present in humans, a new class of short peptides is under development that has been identified by screening peptide libraries against known disease targets. They are artificial agonistic or antagonistic peptide ligands. Peptibodies, composed of artificial peptides fused to Fc, have been primarily developed by Amgen. One such peptide was identified by screening phage display libraries based on binding to thrombopoietin receptor, to which the endogenous protein ligand, thrombopoietin, binds. This 14 amino acid peptide serves as an agonistic ligand and stimulates platelet production, and thus can be used in thrombocytopenic patients. The Fc-fusion of the peptide (romiplostin/Nplate ${ }^{\circledR}$ ) contains 2 tandem repeats of the peptide, as schematically shown in Figure $4 \mathrm{C}$, and thus four peptides in dimeric Fc construct. This should increase the avidity for receptor binding. It appears that fusion at the $\mathrm{C}$-terminus of Fc renders the peptide more active. One potential source of such differences may be due to the structure. As in many peptides, these artificial short peptides may be disordered, flexible, and with the tendency to aggregate. These properties may be affected by surrounding the structure of $\mathrm{Fc}$ (and constraining the overall peptide structure) by fusion (either the $\mathrm{N}$ - or C-terminus of the peptides). Such structural constraint may be stronger if the peptides are inserted into the $\mathrm{CH} 3$ domain of the $\mathrm{Fc}$, as shown in Figure 4C. Apparently, this insertion was designed to have no impact on Fc binding to the Fc receptor and recycling of the peptibody through binding to cell surface FcRn [222].

Neither structural nor aggregation propensity of the peptides by themselves, or in the peptibodies, has been reported. However, one of the functional peptides, SEYQGLCTRWPWMCPPQGWK, in a peptibody (called "peptibody A") [223] has been reported to mediate self-association by increasing the salt concentration (to $150 \mathrm{mM}$ ) and solution $\mathrm{pH}$ (from $\mathrm{pH} 5$ to 7). More specifically, peptibody A demonstrated a strong tendency to self-associate, with no involvement of its Fc domain in physiological solution. Considering the high solubility of the Fc domain, the results appear to suggest that this artificial functional peptide may possess a strong tendency to aggregate, even with the structural rigidity imposed by a disulfide bridge (through 2 Cys in the sequence).

\section{Other mAb-based Therapeutics}

\section{Bispecific}

Bispecific, monovalent antibodies were first described in 1961 by Nisonoff and Rivers [224]. The binding of at least two molecular targets with one single bispecific antibody (bsAb) is an attractive therapeutic concept. Bispecific compounds are being developed to enable: (1) simultaneous inhibition of two cell surface receptors; (2) simultaneous blocking of two ligands; (3) cross linking of two receptors; and (4) recruitment of T-cells to the proximity of tumor cells; to name a few [225]. The formats currently employed include tandem single chain Fv ( $\mathrm{scFv}$ ), diabodies, tandem diabodies, dual variable domain antibodies, and hetero-dimerization [226] (Figure 5). The most advanced bispecific antibody formats include Triomab® and BiTE®, which will be described further below. bsAb, as a 
single molecular entity, may provide a viable alternative to combination therapy with two mAbs (i.e., mAb cocktail, as will be described further below).

Figure 5. Illustration of various bispecific antibodies, including bispecific T-cell engager (BiTE®), Dual-Affinity Re-Targeting $\left(\mathrm{DART}^{\mathrm{TM}}\right)$, tetravalent bispecific recombinant antibody (Tand $A b \AA)$, and Immune mobilizing mTCR Against Cancer (ImmTAC). Figure from May et al. [225].

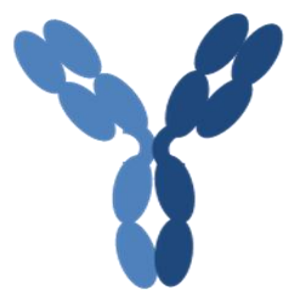

Quadroma

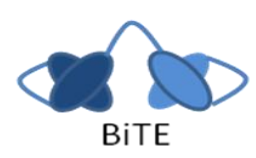

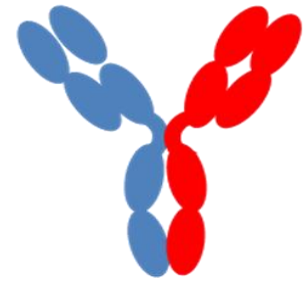

Triomab

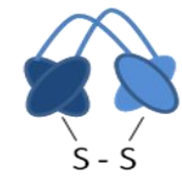

DART

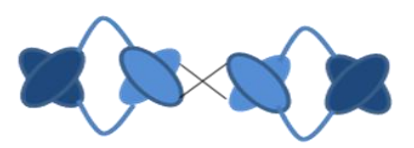

TandAb

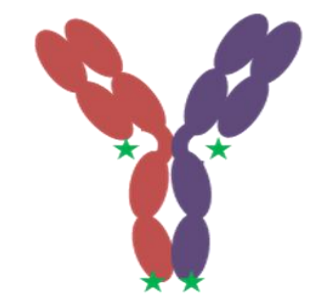

Human $\operatorname{lgG}_{1} / \operatorname{lgG}_{3}$ bsAb

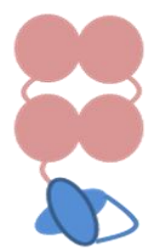

ImmTAC

bsAbs that bind two antigens on the same cell can be used to enhance specificity for cells expressing both targets relative to cells expressing only one [198,227,228]. This was validated at the preclinical level by $\mathrm{Zu}$ and colleagues using a single-gene bispecific diabody (bs-diabody) specific for VEGFR2 (KDR) and VEGFR3 (Flt-4) [229,230]. bsAbs enables an increase in the number of antigen targets, and potentially to overcome tumor immune escape mediated by down-regulation or loss of MHC [231]. In another application, bsAbs have been designed with one specificity directed towards a tumor antigen and the other designed for activation and retargeting of natural killer (NK) cells and myeloid effector cells [232]. Similar to redirected toxicity utility, bsAbs can also be used for rapid clearance of pathogens from the body [233,234]. Moreover, bsAbs can be used for the specific targeting of toxins [235], chemotherapeutic drugs [236], and radioisotopes to tumor cells [237]. Majority of both bispecific diabodies and bis-scFv are designed to bind to the CD3 T-cell co-receptor, and thus recruit cytotoxic T-cells to the tumor site [238]. In contrast, bispecific T-cell engagers (BiTEs®) are capable of efficiently redirecting T-cell cytotoxicity against various target cells without any requirement for pre- or co-stimulation of effector T cells [239,240].

Antibodies with a dual specificity in their binding arms usually do not occur in nature, and thus needs to be engineered using recombinant DNA or cell-fusion technology. The first approach employed to construct and produce bsAbs was the quadroma technology [241,242], which is based on the somatic fusion of two different hybridoma cell lines expressing murine monoclonal antibodies. 
Bispecific antibodies from quadroma cell lines closely resemble conventional mAbs; besides the dualspecific antigen binding fragment $(\mathrm{Fab})$ parts, they contain an $\mathrm{Fc}_{\gamma}$ part, and thus can be considered trispecific. A major improvement to the conventional quadroma approach employed the somatic fusion of a murine and a rat hybridoma cell line, expressing monoclonal antibodies with two IgG subclasses selected for their preferential pairing [15,243]. The hybrid antibodies generated by this method incorporated binding sites for two different antigens while retaining its intact Fc. These trifunctional antibodies, termed TriomAbs, have the combined effect of redirecting $\mathrm{T}$ cells, along with $\mathrm{Fc}$ receptor expressing cells, to the tumor, and have been reported to eliminate tumor cells by a combination of T-cell mediated lysis and ADCC [15]. bsAbs without Fc regions can be prepared and may have better tissue penetration, although they will have short serum half-lives, as will be discussed later in the $m A b$ fragment section. Other explored approaches include: (1) chemical conjugation of two different monoclonal antibodies or smaller antibody fragments [244], (2) 'Knobs-into-holes' strategy [245,246], and (3) strand-exchange engineered domain (SEED) [247].

Alternative recombinant strategies focused on smaller bispecific antibody constructs. In diabodies, each $\mathrm{V}_{\mathrm{L}}$ domain is connected by a short peptide linker to the $\mathrm{V}_{\mathrm{H}}$ domain of the other antigen specificity, and vice versa [248]. Co-expression of respective $\mathrm{V}_{\mathrm{H}}-\mathrm{V}_{\mathrm{L}}$ fusions in the periplasm of E. coli resulted in stable bispecific diabodies. Further extension of diabodies, tandem diabodies [249], has also been manufactured. An alternative small format is the arrangement of two scFvs connected by a flexible polypeptide linker on a single polypeptide chain [250]. BiTE® antibodies are recombinant protein constructs created by linking two scFv molecules via a five amino acid peptide linker [251]. Some key features of BiTEs ${ }^{\circledR}$ include cell surface antigen-dependent polyclonal T-cell activation, potent T-cell mediated serial lysis, and the induction of T-cell proliferation. The short serum half-life of BiTE® antibodies (several hours) allows for rapid-clearance, which may be considered a safety feature of this highly potent class of therapeutic bsAbs. The first BiTE® developed by Micromet, blinatumomab, is a recombinant anti-CD3 $\times$ anti-CD19, and is the most advanced BiTE® in clinical trials [252,253]. Blinatumomab is being studied as a treatment of patients with relapsed NHL and acute lymphblastic leukemia. A competing recombinant format based on a covalently-linked bispecific diabody, termed DARD® (Dual-Affinity Re-Targeting), was reported by the biotechnology company MacroGenics Inc [254,255].

Several other technologies are currently being pursued, including dual-variable domain immunoglobulin (DVD-Ig ${ }^{\mathrm{TM}}$ ) for the generation of an Fv-bispecific molecule [256], and $\mathrm{mAb}^{2} \mathrm{TM}^{\mathrm{TM}}$ antibodies, produced by Modular Antibody Technology platform (f-star inc., [257] and ImmTAC (immune mobilizing monoclonal TCR against cancer; Immunocore, [258]).

The vast majority of bispecific Abs developed in oncology are undergoing preclinical evaluation. HRS-3/A9 is a CD16-directed bispecific antibody already tested in clinical trials [232,259]. The compound is a bispecific $\mathrm{F}(\mathrm{ab})_{2}$ antibody (without $\mathrm{F}_{\mathrm{c} \gamma}$ part) targeting the CD30 antigen on Hodgkin and Reed-Sternberg cells in patients with Hodgkin's Disease. Of the bsAbs derived using quadroma technology, the Triomab® (TRION Research GmbH, Munich, Germany) class is the most encouraging thus far [243]. Catumaxomab is the most clinically advanced Triomab® [15]. Catumaxomab combines two half antibodies of mouse anti-EpCAM IgG2a and rat anti-CD3 IgG2b [260]. In a randomized Phase II/III study involving 258 patients with malignant ascites, catumaxomab demonstrated significant improvement in survival, which led to EU approval in 2009 for the treatment of malignant 
ascites in patients with EpCAM-positive tumors, and was the first bispecific antibody approved for clinical use [15,261].

Despite the advantages discussed above, there are several hurdles that need to be overcome for bsAbs to be considered a viable alternative therapy. The primary challenges with bsAbs include chemical manufacturing control issues, production yield and purity, and poor clinical results associated with early formats. Although producing small amounts for in vitro studies and animal models may be relatively straightforward, high and affordable production yields, as needed, for clinical grade material will require major efforts.

\section{7. mAb Fragments}

Smaller recombinant antibody fragments (i.e., Fab, $\mathrm{scFv}$, and single variable $\mathrm{V}_{\mathrm{H}}$ and $\mathrm{V}_{\mathrm{L}}$ domains) and engineered variants (diabodies, triabodies, minibodies, and single-domain antibodies) are now emerging as viable alternatives to mAbs (Figure 6). These fragments retain the targeting specificity of whole mAbs while possessing additional unique properties for a range of diagnostic and therapeutic applications. For example, diffusion has been reported to play a prominent role in the transport of molecules within tumors [262]. Smaller constructs such as scFv, diabodies, triabodies, minibodies, and Fabs have been shown in xenograft systems to possess shorter half-lives and accumulate at higher tumor-to-organ ratios in comparison to corresponding Fab' ${ }_{2}$ constructs [263,264]. Similarly, scFvs have been reported to efficiently penetrate certain tissue barriers due to their more efficient extravasation from blood vessels and improved diffusion in the extracellular matrix, in comparison to a $\mathrm{mAb}$ [265]. ESBA105, a TNF-alpha inhibitory scFv, have been reported to penetrate through ocular epithelial barriers and reach therapeutic concentrations in different ocular compartments including the vitreous humor and retina [266]. It is hypothesized that its excellent tissue penetration properties may also facilitate delivery into the CNS for the treatment of neurological disorders, following either intranasal or systemic administration. In another example, many pathogenic viruses have evolved narrow cavities in their surface antigens to escape immunosurveillance [267]. Compared to monoclonal antibodies, camelid $\mathrm{VhH}$ and shark V-NAR domains display long surface loops, and are thus able to penetrate cavities in target antigens [268-270]. Similarly, HIV-1 has evolved a number of strategies to evade humoral immunity [271]. A human dAb (domain antibody; $15 \mathrm{kDa}$ ), m36, has been shown to target a highly protected structure on the HIV-1 envelope glycoprotein (Env), gp120, and exhibit exceptionally potent neutralizing activity against HIV-1 primary isolates, with higher potency on average than those of the broadly cross-reactive mAbs [272].

Fab fragments $(55 \mathrm{kDa})$, obtained by proteolytic digestion of $\mathrm{IgG}$, are typically composed of a single antibody light chain linked by a disulfide bond to a heavy chain fragment, which represents a single binding site for the antigen. $(\mathrm{Fab})_{2}$ fragments are bivalent and retain the heavy chain hinge region. Single-chain Fvs (scFv; $25 \mathrm{kDa}$ ) are a popular format in which the $\mathrm{V}_{\mathrm{H}}$ and $\mathrm{V}_{\mathrm{L}}$ domains are joined using a flexible polypeptide linker [274]. $\mathrm{scFv}$ molecules can also be engineered to enable the formation of an $(\mathrm{scFv})_{2}$ fragment by virtue of disulfide bridging. Diabody is a bivalent molecule, formed by linking two scFvs non-covalently [275]. Diabodies have rigid, compact structures, which allow for lower separation of the two binding sites and possess an excellent combination of rapid tumor uptake and clearance for in vivo imaging [276,277]. Minibody is an alternative to diabody, in 
which $2 \mathrm{scFv}$ fragments are linked by a component of the heavy-chain region [278]. Single-domain antibodies (dAbs, 11-15 kDa) have been engineered and selected as targeting reagents against hitherto immunosilent cavities in enzymes, receptors, and infectious agents.

Figure 6. Schematic representation of various antibody formats, including the intact IgG molecule alongside various representations of antibody fragments. Figure from Holliger and Hudson [273].

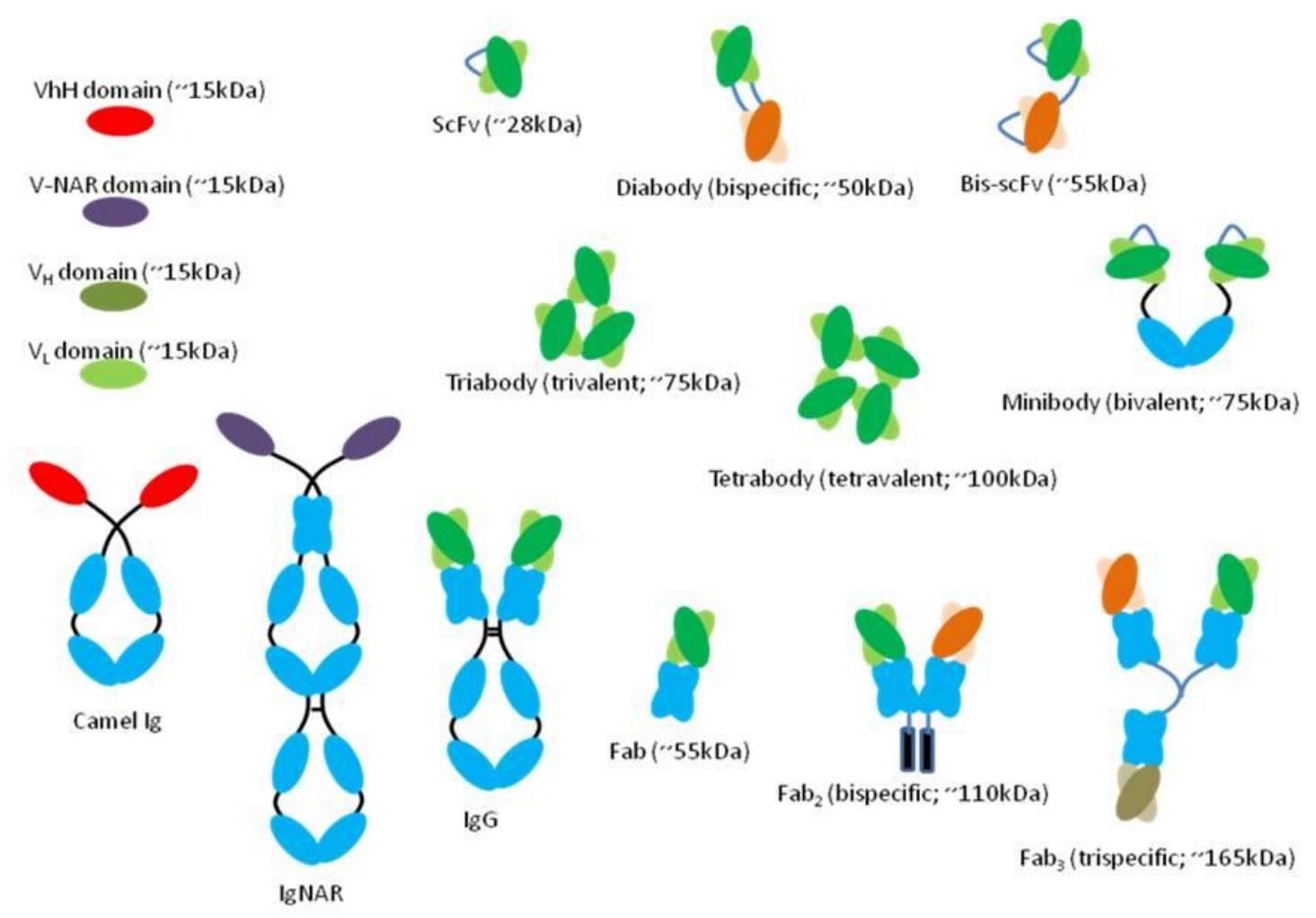

In addition, antibody fragments have been linked or fused genetically to a vast range of molecules that provide important ancillary functions, following target binding. These include radionuclides, cytotoxic drugs, toxins, peptides, proteins, enzymes, and liposomes for improved drug delivery, and even viruses for targeted gene therapy [279-281]. Another concept that has been galvanized by progress in $\mathrm{mAb}$-fragment engineering is antibody-directed enzyme prodrug therapy (ADEPT). In this strategy, mAb fragments (for example, a humanized scFv [282] or camelid VhH [283]) are fused to enzymes (such as $\beta$-lactamase and carboxypeptidase), which catalyze prodrug activation.

Domantis developed phage display libraries of fully human $\mathrm{V}_{\mathrm{H}^{-}}$and $\mathrm{V}_{\mathrm{L}}$-chain $\mathrm{dAbs}$ to select single variable domain-based antibodies (called domain antibodies) against a variety of therapeutic targets [284]. Ablynx Inc. has used the immunization approach to generate single variable domainbased antibodies called nanobodies [285,286]. These dAbs and nanobodies are approximately $13 \mathrm{kDa}$ in size, bind antigens with high affinity and express well in both microbial and mammalian cells. These functionally active dAbs and nanobodies can be reformatted into a linked dAb or CH1/CL dAb, or be attached to $\mathrm{V}_{\mathrm{H}}$ and/or $\mathrm{V}_{\mathrm{L}}$ chains, or the $\mathrm{CH} 3$ of a regular antibody to make a bispecific or multispecific molecule [287].

Efficient methods of gene delivery, with localized functional expression of the encoded product, are still in their infancy, however when successful, in situ expression will provide an attractive alternative 
to systemic administration of antibody fragments [288]. In fact, in situ expression and secretion of cytotoxic scFv fragments [289] or a bispecific diabody [290] (termed intrabodies) in vivo from just a few expressor cells have been reported to promote significant growth inhibition of established tumor xenografts. Like their extracellular counterparts, intrabodies may be engineered into multivalent and multispecific forms to enhance their efficacy [291].

The major hurdles reported with the various scFv-based formats relate to low yields, poor product quality (high aggregation propensity and product heterogeneity), poor stability, and in vivo loss of activity. Numerous expression systems have been evaluated and compared [292,293]; in summary, mammalian or plant cells are the favored hosts for high-yield expression of larger intact antibodies and minibodies, whereas bacterial and yeast systems are most useful for mAb fragments and $\mathrm{V}$ domains. The pharmacokinetics and pharmacodynamics of these agents should be carefully investigated, since their molecular structure cannot be compared with those of conventional monoclonal antibodies.

\section{1. mAb Cocktail}

Theoretical drawback of mAb therapy is that these reagents, by definition, target a single epitope, and provide one type of effector function corresponding to their isotype. The potent neutralizing ability of mAbs can inadvertently result in increased antigenic escape in experimental infection with highly variant RNA viruses. Indeed, treatment with a single mAb has culminated in escape variants in HIV [294], hepatitis C virus [295], and influenza A [296]. This problem may be counterbalanced by selecting mAbs that target conserved areas of viral particles or by using mixtures of mAbs that target various epitopes. For example, combination therapy with $\mathrm{mAb}$ cocktails has been reported to prevent escape variants for many viruses including influenza [297], hepatitis B virus [298], and rabies virus [299]. Originally a poly Ig product, RespiGam ${ }^{\circledR}$ was developed by MedImmune and approved for prophylactic use in infants. While efficacious, a humanized IgG1 mAb product (Synagis®, palivizumab) was designed to replace RespiGam®. In vitro and in vivo experiments have demonstrated that antibody combinations can not only show an additive effect, but also a synergistic effect on target cell populations [300-302]. As early as 1982, combinations of two mAbs against the vesicular stomatitis virus have been demonstrated to act synergistically in virus neutralization, and similar findings were subsequently reported for other viruses, including rabies [303] and HIV [304-306]. Synergistic or additive effects of cocktails of mAbs are not restricted to virus neutralization. In oncology and infectious diseases, cocktails of two conventionally manufactured mAbs are used for targeting HER2/neu (breast cancer [307]) and CD20 and CD22 (non-Hodgkin's lymphoma [308]). In addition, mixtures of three mAbs against botulinum toxin were demonstrated to have almost 100-fold higher potency than that reported for human polyclonal botulinum-immune globulin or individual mAbs [309]. mAb cocktail also has widened biological effector functions as it consists of multiple classes of antibodies. The ability to induce ADCC or CDC is dependent on both the isotype and glycosylation status of the antibody [310], thus the variability inherent in polyclonal preparations should provide added benefit and a protective advantage.

$\mathrm{mAb}$ cocktails address two major problems posed by targeting a single epitope. First, by targeting two neutralizing epitopes, at minimum, escape mutants generated from each $\mathrm{mAb}$ are cleared by the complementing antibody [297]. In addition, mAb cocktails further add to the 'functional specificity' of 
antibody therapy by selectively targeting tumor cells with the correct antigenic make-up, based on combinations of target molecules, while leaving non-tumor cells unharmed. Second, by increasing the antibody density on the viral surface, which may be the most important factor in virus neutralization [311], the neutralizing ability of the antibody is amplified considerably [312]. It is becoming evident that treatment of an infectious disease with multiple mAbs is most probably required to provide optimal protection. This concept is not novel, however. In the late 1890s Behring and Kitasato developed the first widely available and effective antimicrobial treatment by showing that transfer of immune sera could provide passive immunity to diphtheria [313]. Following the discovery, serum therapy was used against a diverse range of infectious diseases, including pneumococcal pneumonia, meningococcal meningitis, erysipelas, anthrax and others [1,314].

Several methods for the production of mAb cocktails have been documented. In one strategy, animals are genetically manipulated to harbor human immunoglobulin loci, and the animal's endogenous immunoglobulin loci are inactivated [19]. Upon immunization, these transgenic animals produce human antibodies, and the pooled sera could be used to prepare human polyclonal antibody therapeutics. However, batch-to-batch variation, risk of disease transmission, and precise control over the antibody composition of the polyclonal sera, are potential issues. Another manufacturing approach exploits a single master cell bank, comprising a mixture of clonal cell lines that each produces a single human $\mathrm{mAb}$ [315]. This approach requires the development of large numbers of cell lines that each stably secrete sufficient amounts of $\mathrm{mAb}$ to contribute to the mixture. Furthermore, individual cell lines in the mixture could have different growth characteristics, which will result in asymmetrical contribution of individual mAbs to the eventual mixture and, probably, batch-to-batch variation. An alternative approach uses a technology platform that permits the stable and high-yield production of multiple mAbs from clonal cell lines [315]. Genetic constructs encoding three to five different mAbs are inserted into a single cell, and antibody cocktails consisting of bivalent and bispecific IgG molecules are produced. The advantages of this approach are that it requires the development of only a single cell line for a cocktail of $\mathrm{mAbs}$ and that the requirements for production runs are similar to those for conventional mAbs.

Despite the advantages mentioned above, there must also be caution. A potentially serious complication of antibody cocktail therapy is the development of antagonistic effects. For example, should any one of the administered antibodies lose efficacy in vitro, then there may be antagonistic effects that need to be fully understood. With three or more antibodies formulated together, it is reasonable to assume that each will have different in vivo pharmacokinetics. Furthermore, mixing independently generated mAbs to concoct a more potent therapeutic may not be commercially viable due to the high cost of development [316]. In addition, clinical phase trials may be more complex due to the various $\mathrm{mAb}$ combinations possible (i.e., combined drug product, sequential injections, etc.). In addition, the inclusion of multiple immunoglobulins in any therapeutic formulation is fraught with complex regulatory and licensing issues. Nevertheless, progress in overcoming these burdensome regulatory issues is evidenced by the recent development of a mAb mixture for the prophylaxis of rabies that targets several virus types [303]. 


\section{Summary}

With the number of viable mAb-based therapy increasing, it is evident that the focus of the biotherapeutics industry will continue to be mAbs or their derivatives. To provide the effective dose, the currently available options are to prepare $\mathrm{mAb}$ formulations at high concentration, deliver a high volume, or to engineer enhanced targeting capability. The issues described in the current review for the preparation of high concentration $\mathrm{mAb}$ formulations include manufacturing challenges, stability, and delivery. Various mAb-based modalities are also under development, including ADCs, fusion proteins, and bsAbs, to circumvent some of the issues encountered with mAb therapies; nevertheless, similar issues may still be encountered with alternative mAb-based products. Though promising results have been obtained, there are still challenges to be overcome. Nonetheless, it is difficult to ignore the benefits of expanding therapeutic tools that have become available, as well as the improvements in our capability to manufacture, analyze, and formulate these complex biologicals.

\section{Conflict of Interest}

The authors declare no conflict of interest.

\section{References}

1. Casadevall, A.; Scharff, M.D. Return to the past: The case for antibody-based therapies in infectious diseases. Clin. Infect. Dis. 1995, 21, 150-161.

2. Bruton, O.C. Agammaglobulinemia. Pediatrics 1952, 9, 722-728.

3. Nadler, L.M.; Stashenko, P.; Hardy, R.; Kaplan, W.D.; Button, L.N.; Kufe, D.W.; Antman, K.H.; Schlossman, S.F. Serotherapy of a patient with a monoclonal antibody directed against a human lymphoma-associated antigen. Cancer Res. 1980, 40, 3147-3154.

4. Kohler, G.; Milstein, C. Continuous cultures of fused cells secreting antibody of predefined specificity. Nature 1975, 256, 495-497.

5. Oldham, R.K. Monoclonal antibodies as anticancer agents. Adv. Exp. Med. Biol. 1983, 166, 45-57.

6. Reichert, J.M. Metrics for antibody therapeutics development. MAbs 2010, 2, 695-700.

7. Marks, L. The birth pangs of monoclonal antibody therapeutics: The failure and legacy of Centoxin. MAbs 2012, 4, 403-412.

8. Hurley, J.C. Sepsis management and antiendotoxin therapy after nebacumab. A reappraisal. Drugs 1994, 47, 855-861.

9. Beck, A.; Wurch, T.; Bailly, C.; Corvaia, N. Strategies and challenges for the next generation of therapeutic antibodies. Nat. Rev. Immunol. 2010, 10, 345-352.

10. Coiffier, B.; Lepage, E.; Brière, J.; Herbrecht, R.; Tilly, H.; Bouabdallah, R.; Morel, P.; Van Den Neste, E.; Salles, G.; Gaulard, P.; et al. CHOP chemotherapy plus rituximab compared with CHOP alone in elderly patients with diffuse large-B-cell lymphoma. N. Engl. J. Med. 2002, 346, 235-242.

11. McLaughlin, P.; Grillo-López, A.J.; Link, B.K.; Levy, R.; Czuczman, M.S.; Williams, M.E.; Heyman, M.R.; Bence-Bruckler, I.; White, C.A.; Cabanillas, F.; et al. Rituximab chimeric anti-CD20 monoclonal antibody therapy for relapsed indolent lymphoma: Half of patients respond to a four-dose treatment program. J. Clin. Oncol. 1998, 16, 2825-2833. 
12. Reichert, J.M. Antibody-based therapeutics to watch in 2011. MAbs 2011, 3, 76-99.

13. Sievers, E.L.; Appelbaum, F.R.; Spielberger, R.T.; Forman, S.J.; Flowers, D.; Smith, F.O.; Shannon-Dorcy, K.; Berger, M.S.; Bernstein, I.D. Selective ablation of acute myeloid leukemia using antibody-targeted chemotherapy: A phase I study of an anti-CD33 calicheamicin immunoconjugate. Blood 1999, 93, 3678-3684.

14. Weiner, L.M.; Surana, R.; Wang, S. Monoclonal antibodies: Versatile platforms for cancer immunotherapy. Nat. Rev. Immunol. 2010, 10, 317-327.

15. Linke, R.; Klein, A.; Seimetz, D. Catumaxomab: Clinical development and future directions. MAbs 2010, 2, 129-136.

16. Wang, W.; Singh, S.; Zeng, D.L.; King, K.; Nema, S. Antibody structure, instability, and formulation. J. Pharm. Sci. 2007, 96, 1-26.

17. Oldham, R.K.; Dillman, R.O. Monoclonal antibodies in cancer therapy: 25 years of progress. J. Clin. Oncol. 2008, 26, 1774-1777.

18. Hoogenboom, H.R. Selecting and screening recombinant antibody libraries. Nat. Biotechnol. 2005, 23, 1105-1116.

19. Lonberg, N. Human antibodies from transgenic animals. Nat. Biotechnol. 2005, 23, 1117-1125.

20. McCafferty, J.; Griffiths, A.D.; Winter, G.; Chiswell, D.J. Phage antibodies: Filamentous phage displaying antibody variable domains. Nature 1990, 348, 552-554.

21. Clynes, R.A.; Towers, T.L.; Presta, L.G.; Ravetch, J.V. Inhibitory Fc receptors modulate in vivo cytotoxicity against tumor targets. Nat. Med. 2000, 6, 443-446.

22. Graziano, R.F.; Fanger, M.W. Fc gamma RI and Fc gamma RII on monocytes and granulocytes are cytotoxic trigger molecules for tumor cells. J. Immunol. 1987, 139, 3536-3541.

23. Kimura, H.; Sakai, K.; Arao, T.; Shimoyama, T.; Tamura, T.; Nishio, K. Antibody-dependent cellular cytotoxicity of cetuximab against tumor cells with wild-type or mutant epidermal growth factor receptor. Cancer Sci. 2007, 98, 1275-1280.

24. Jain, R.K. Normalizing tumor vasculature with anti-angiogenic therapy: A new paradigm for combination therapy. Nat. Med. 2001, 7, 987-989.

25. Chan, A.C.; Carter, P.J. Therapeutic antibodies for autoimmunity and inflammation. Nat. Rev. Immunol. 2010, 10, 301-316.

26. Ducancel, F.; Muller, B.H. Molecular engineering of antibodies for therapeutic and diagnostic purposes. MAbs 2012, 4, 445-457.

27. Dillman, R.O. Magic bullets at last! Finally-Approval of a monoclonal antibody for the treatment of cancer!!! Cancer Biother. Radiopharm. 1997, 12, 223-225.

28. Huhn, D.; von Schilling, C.; Wilhelm, M.; Ho, A.D.; Hallek, M.; Kuse, R.; Knauf, W.; Riedel, U.; Hinke, A.; Srock, S.; et al. Rituximab therapy of patients with B-cell chronic lymphocytic leukemia. Blood 2001, 98, 1326-1331.

29. Nelson, A.L.; Dhimolea, E.; Reichert, J.M. Development trends for human monoclonal antibody therapeutics. Nat. Rev. Drug Discov. 2010, 9, 767-774.

30. Wormald, M.R.; Dwek, R.A. Glycoproteins: Glycan presentation and protein-fold stability. Structure 1999, 7, R155-R160.

31. Yamane-Ohnuki, N.; Satoh, M. Production of therapeutic antibodies with controlled fucosylation. MAbs 2009, 1, 230-236. 
32. Lis, H.; Sharon, N. Protein glycosylation. Structural and functional aspects. Eur. J. Biochem. 1993, 218, 1-27.

33. Mimura, Y.; Churcha, S.; Ghirlandob, R.; Ashtonc, P.R.; Donga, S.; Goodalla, M.; Lunda, J.; Jefferisa, R. The influence of glycosylation on the thermal stability and effector function expression of human IgG1-Fc: Properties of a series of truncated glycoforms. Mol. Immunol. 2000, 37, 697-706.

34. Kayser, V.; Chennamsetty, N.; Voynov, V.; Forrer, K.; Helk, B.; Trout, B.L. Glycosylation influences on the aggregation propensity of therapeutic monoclonal antibodies. Biotechnol. J. 2011, 6, 38-44.

35. Runkel, L.; Meier, W.; Blake Pepinsky, R.; Karpusas, M.; Whitty, A.; Kimball, K.; Brickelmaier, M.; Muldowney, C.; Jones, W.; Goelz, S.E. Structural and functional differences between glycosylated and non-glycosylated forms of human interferon-beta (IFN-beta). Pharm. Res. 1998, 15, 641-649.

36. Sondermann, P.; Huber, R.; Oosthuizen, V.; Jacob, U. The 3.2-A crystal structure of the human IgG1 Fc fragment-Fc gammaRIII complex. Nature 2000, 406, 267-273.

37. Burton, D.R.; Woof, J.M. Human antibody effector function. Adv. Immunol. 1992, 51, 1-84.

38. Anegon, I.; Cuturi, M.C.; Trinchieri, G.; Perussia, B. Interaction of Fc receptor (CD16) ligands induces transcription of interleukin 2 receptor $(\mathrm{CD} 25)$ and lymphokine genes and expression of their products in human natural killer cells. J. Exp. Med. 1988, 167, 452-472.

39. Fanger, M.W.; Graziano, R.F.; Li, S.; Guyre, P.M. Fc gamma R in cytotoxicity exerted by mononuclear cells. Chem. Immunol. 1989, 47, 214-253.

40. Anderson, C.L.; Shen, L.; Eicher, D.M.; Wewers, M.D.; Gill, J.K. Phagocytosis mediated by three distinct Fc gamma receptor classes on human leukocytes. J. Exp. Med. 1990, 171, 1333-1345.

41. Jefferis, R.; Lund, J.; Pound, J.D. IgG-Fc-mediated effector functions: Molecular definition of interaction sites for effector ligands and the role of glycosylation. Immunol. Rev. 1998, 163, 59-76.

42. Vugmeyster, Y.; Howell, K. Rituximab-mediated depletion of cynomolgus monkey B cells in vitro in different matrices: Possible inhibitory effect of IgG. Int. Immunopharmacol. 2004, 4, 1117-1124.

43. Matsumiya, S.; Yamaguchi, Y.; Saito, J.; Nagano, M.; Sasakawa, H.; Otaki, S.; Satoh, M.; Shitara, K.; Kato, K. Structural comparison of fucosylated and nonfucosylated Fc fragments of human immunoglobulin G1. J. Mol. Biol. 2007, 368, 767-779.

44. Ferrara, C.; Stuart, F.; Sondermann, P.; Brünker, P.; Umaña, P. The carbohydrate at FcgammaRIIIa Asn-162. An element required for high affinity binding to non-fucosylated IgG glycoforms. J. Biol. Chem. 2006, 281, 5032-5036.

45. Iida, S.; Misaka, H.; Inoue, M.; Shibata, M.; Nakano, R.; Yamane-Ohnuki, N.; Wakitani, M.; Yano, K.; Shitara, K.; Satoh, M. Nonfucosylated therapeutic IgG1 antibody can evade the inhibitory effect of serum immunoglobulin $G$ on antibody-dependent cellular cytotoxicity through its high binding to FcgammaRIIIa. Clin. Cancer Res. 2006, 12, 2879-2887.

46. Shitara, K. Potelligent antibodies as next generation therapeutic antibodies. Yakugaku Zasshi 2009, 129, 3-9.

47. Wang, W. Instability, stabilization, and formulation of liquid protein pharmaceuticals. Int. J. Pharm. 1999, 185, 29-88. 
48. Mahler, H.C.; Friess, W.; Grauschopf, U.; Kiese, S. Protein aggregation: Pathways, induction factors and analysis. J. Pharm. Sci. 2009, 98, 2909-3934.

49. Daugherty, A.L.; Mrsny, R.J. Formulation and delivery issues for monoclonal antibody therapeutics. Adv. Drug Deliv. Rev. 2006, 58, 686-706.

50. Parkins, D.A.; Lashmar, U.T. The formulation of biopharmaceutical products. Pharm. Sci. Technol. Today 2000, 3, 129-137.

51. Narhi, L.O.; Jiang, Y.; Cao, S.; Benedek, K.; Shnek, D. A critical review of analytical methods for subvisible and visible particles. Curr. Pharm. Biotechnol. 2009, 10, 373-381.

52. Das, T.K. Protein particulate detection issues in biotherapeutics development - Current status. AAPS PharmSciTech. 2012, 13, 732-746.

53. Karshikoff, A. Non-Covalent Interactions in Proteins, 1st ed.; Imperial College Press: London, UK, 2006.

54. Andya, J.D.; Hsu, C.C.; Shire, S.J. Mechanisms of aggregate formation and carbohydrate excipient stabilization of lyophilized humanized monoclonal antibody formulations. AAPS PharmSci. 2003, 5, E10.

55. Malencik, D.A.; Anderson, S.R. Dityrosine as a product of oxidative stress and fluorescent probe. Amino Acids 2003, 25, 233-247.

56. Hawe, A.; Kasperb, J.C.; Friessb, W.; Jiskoota, W. Structural properties of monoclonal antibody aggregates induced by freeze-thawing and thermal stress. Eur. J. Pharm. Sci. 2009, 38, 79-87.

57. Kreilgaard, L.; Jones, L.S.; Randolph, T.W.; Frokjaer, S.; Flink, J.M.; Manning, M.C.; Carpenter, J.F. Effect of Tween 20 on freeze-thawing- and agitation-induced aggregation of recombinant human factor XIII. J. Pharm. Sci. 1998, 87, 1597-1603.

58. Strambini, G.B.; Gonnelli, M. Protein stability in ice. Biophys. J. 2007, 92, 2131-2138.

59. Pikal-Cleland, K.A.; Cleland, J.L.; Anchordoquy, T.J.; Carpenter, J.F. Effect of glycine on pH changes and protein stability during freeze-thawing in phosphate buffer systems. J. Pharm. Sci. 2002, 91, 1969-1979.

60. Kueltzo, L.A.; Wang, W.; Randolph, T.W.; Carpenter, J.F. Effects of solution conditions, processing parameters, and container materials on aggregation of a monoclonal antibody during freeze-thawing. J. Pharm. Sci. 2008, 97, 1801-1812.

61. Schreiber, G. Kinetic studies of protein-protein interactions. Curr. Opin. Struct. Biol. 2002, 12, 41-47.

62. Cleland, J.L.; Powell, M.F.; Shire, S.J. The development of stable protein formulations: A close look at protein aggregation, deamidation, and oxidation. Crit. Rev. Ther. Drug Carrier. Syst. 1993, 10, 307-377.

63. Tyler-Cross, R.; Schirch, V. Effects of amino acid sequence, buffers, and ionic strength on the rate and mechanism of deamidation of asparagine residues in small peptides. J. Biol. Chem. 1991, 266, 22549-22556.

64. Son, K.; Kwon, C. Stabilization of human epidermal growth factor (hEGF) in aqueous formulation. Pharm. Res. 1995, 12, 451-454.

65. Daniel, R.M.; Dines, M.; Petach, H.H. The denaturation and degradation of stable enzymes at high temperatures. Biochem. J. 1996, 317, 1-11. 
66. Strickley, R.G.; Anderson, B.D. Solid-state stability of human insulin. I. Mechanism and the effect of water on the kinetics of degradation in lyophiles from $\mathrm{pH} 2-5$ solutions. Pharm. Res. 1996, 13, 1142-1153.

67. Cacia, J.; Keck, R.; Presta, L.G.; Frenz, J. Isomerization of an aspartic acid residue in the complementarity-determining regions of a recombinant antibody to human IgE: Identification and effect on binding affinity. Biochemistry 1996, 35, 1897-1903.

68. Li, S.; Schoneich, C.; Borchardt, R.T. Chemical pathways of peptide degradation. VIII. Oxidation of methionine in small model peptides by prooxidant/transition metal ion systems: Influence of selective scavengers for reactive oxygen intermediates. Pharm. Res. 1995, 12, 348-355.

69. Powell, M.F. A compendium and hydropathy/flexibility analysis of common reactive sites in proteins: Reactivity at Asn, Asp, Gln, and Met motifs in neutral pH solution. In Formulation, Characterization, and Stability of Protein Drugs; Pearlman, R., Wang, Y.J., Eds.; Plenum Press: New York, NY, USA, 1996; pp. 1-140.

70. Brange, J.; Langkj, L.; Havelund, S.; Vølund, A. Chemical stability of insulin. 1. Hydrolytic degradation during storage of pharmaceutical preparations. Pharm. Res. 1992, 9, 715-726.

71. Manning, M.C.; Patel, K.; Borchardt, R.T. Stability of protein pharmaceuticals. Pharm. Res. 1989, 6, 903-918.

72. Kroon, D.J.; Baldwin-Ferro, A.; Lalan, P. Identification of sites of degradation in a therapeutic monoclonal antibody by peptide mapping. Pharm. Res. 1992, 9, 1386-1393.

73. Li, S.; Nguyen, T.H.; Schoneich, C.; Borchardt, R.T. Aggregation and precipitation of human relaxin induced by metal-catalyzed oxidation. Biochemistry 1995, 34, 5762-5772.

74. Lam, X.M.; Yang, J.Y.; Cleland, J.L. Antioxidants for prevention of methionine oxidation in recombinant monoclonal antibody HER2. J. Pharm. Sci. 1997, 86, 1250-1255.

75. Ha, E.; Wang, W.; Wang, Y.J. Peroxide formation in polysorbate 80 and protein stability. J. Pharm. Sci. 2002, 91, 2252-2264.

76. Knepp, V.M.; Whatley, J.L.; Muchnik, A.; Calderwood, T.S. Identification of antioxidants for prevention of peroxide-mediated oxidation of recombinant human ciliary neurotrophic factor and recombinant human nerve growth factor. PDA J. Pharm. Sci. Technol. 1996, 50, 163-171.

77. Liu, J.L.; Lu, K.V.; Eris, T.; Katta, V.; Westcott, K.R.; Narhi, L.O.; Lu, H.S. In vitro methionine oxidation of recombinant human leptin. Pharm. Res. 1998, 15, 632-640.

78. Fransson, J.; FIorin-Robertsson, E.; Axelsson, K.; Nyhlén, C. Oxidation of human insulin-like growth factor I in formulation studies: Kinetics of methionine oxidation in aqueous solution and in solid state. Pharm. Res. 1996, 13, 1252-1257.

79. Shahrokh, Z.; Eberlein, G.; Buckley, D.; Paranandi, M.V.; Aswad, D.W.; Stratton, P.; Mischak, R.; Wang, Y.J. Major degradation products of basic fibroblast growth factor: Detection of succinimide and iso-aspartate in place of aspartate. Pharm. Res. 1994, 11, 936-944.

80. Kamat, M.S.; Tolman, G.L.; Brown, J.M. Formulation development of an antifibrin monoclonal antibody radiopharmaceutical. Pharm. Biotechnol. 1996, 9, 343-364.

81. Tous, G.I.; Wei, Z.; Feng, J.; Bilbulian, S.; Bowen, S.; Smith, J.; Strouse, R.; McGeehan, P.; Casas-Finet, J.; Schenerman, M.A. Characterization of a novel modification to monoclonal antibodies: Thioether cross-link of heavy and light chains. Anal. Chem. 2005, 77, 2675-2682. 
82. Hermeling, S.; Crommelin, D.J.A.; Schellekens, H.; Jiskoot, W. Structure-immunogenicity relationships of therapeutic proteins. Pharm. Res. 2004, 21, 897-903.

83. Schellekens, H. Immunogenicity of therapeutic proteins: Clinical implications and future prospects. Clin. Ther. 2002, 24, 1720-1740; discussion 1719.

84. Casadevall, N.; Nataf, J.; Viron, B.; Kolta, A.; Kiladjian, J.-J.; Martin-Dupont, P.; Michaud, P.; Papo, T.; Ugo, V.; Teyssandier, I.; et al. Pure red-cell aplasia and antierythropoietin antibodies in patients treated with recombinant erythropoietin. N. Engl. J. Med. 2002, 346, 469-475.

85. Joubert, M.K.; Hokom, M.; Eakin, C.; Zhou, L.; Deshpande, M.; Baker, M.P.; Goletz, T.J.; Kerwin, B.A.; Chirmule, N.; Narhi, L.O.; et al. Highly aggregated antibody therapeutics can enhance the in vitro innate and late-stage T-cell immune responses. J. Biol. Chem. 2012, 287, 25266-25279.

86. Demeule, B.; Gurny, R.; Arvinte, T. Where disease pathogenesis meets protein formulation: Renal deposition of immunoglobulin aggregates. Eur. J. Pharm. Biopharm. 2006, 62, 121-130.

87. USP. General Chapters: <788> Particulate Matter in Injections; Pharmacopeial Forum: Maryland, MD, USA, 2009; p. USP32-NF27.

88. Harris, R.J.; Kabakoff, B.; Macchi, F.D.; Shen, F.J.; Kwong, M.; Andya, J.D.; Shire, S.J.; Bjork, N.; Totpal, K.; Chen, A.B. Identification of multiple sources of charge heterogeneity in a recombinant antibody. J. Chromatogr. B Biomed. Sci. Appl. 2001, 752, 233-245.

89. Hochuli, E. Interferon immunogenicity: Technical evaluation of interferon-alpha 2a. J. Interferon. Cytokine Res. 1997, 17, S15-S21.

90. Laue, T.M.; Shah, B.; Ridgeway, T.M.; Pelletier, S.L. Computer-aided Interpretation of Sedimentation Data for Proteins. In Analytical Ultracentrifugation in Biochemistry and Polymer Science; Harding,S.E., Rowe, A.J., Horton, J.C., Eds.; Royal Society of Chemistry: Cambridge, UK, 1992; pp. 90-125.

91. Hartmann, W.K.; Saptharishi, N.; Yang, X.Y.; Mitra, G.; Soman, G. Characterization and analysis of thermal denaturation of antibodies by size exclusion high-performance liquid chromatography with quadruple detection. Anal. Biochem. 2004, 325, 227-239.

92. Chiti, F.; van Nuland, N.A.J.; Taddei, N.; Magherini, F.; Stefani, M.; Ramponi, G.; Dobson, C.M. Conformational stability of muscle acylphosphatase: The role of temperature, denaturant concentration, and $\mathrm{pH}$. Biochemistry 1998, 37, 1447-1455.

93. PharmaCircle. Available online: www.pharmacircle.com (accessed on 1 June 2013).

94. Lam, X.M.; Oeswein, O.J.; Ongpipattanakul, B.; Shahrokh, Z.; Weissburg, W.S.; Wong, R.P. Stabilized Antibody Formulation. US Patent, CA 2292730, 1998.

95. Johnson, R.E.; Hong, Q.I.; Borgmeyer, J.R.; Kessler, R.K.; Zeng, D.L. Stable pH optimized formulation of a modified antibody. WO Patent, WO/2004/019861, 2004.

96. Warne, N.W. Development of high concentration protein biopharmaceuticals: The use of platform approaches in formulation development. Eur. J. Pharm. Biopharm. 2011, 78, 208-212.

97. Lee, L.S. Stabilized Monomeric Protein Compositions. US Patent 5,656,730, 1997.

98. Worn, A.; Pluckthun, A. Mutual stabilization of VL and VH in single-chain antibody fragments, investigated with mutants engineered for stability. Biochemistry 1998, 37, 13120-13127. 
99. Horbett, T.A. Protein adsorption on biomaterials. In Biomaterials: Interfacial Phenomena and Applications; Cooper, S.L., Peppas, N.A., Hoffman, A.S., Ratner, B.D., Eds.; American Chemical Society: Washington DC, USA, 1982; pp. 233-244.

100. Lee, H.J.; McAuley, A.; Schilke, K.F.; McGuire, J. Molecular origins of surfactant-mediated stabilization of protein drugs. Adv. Drug Deliv. Rev. 2011, 63, 1160-1171.

101. Kerwin, B.A. Polysorbates 20 and 80 used in the formulation of protein biotherapeutics: Structure and degradation pathways. J. Pharm. Sci. 2008, 97, 2924-2935.

102. Chen, B.; Bautista, R.; Yu, K.; Zapata, G.A.; Mulkerrin, M.G.; Chamow, S.M. Influence of histidine on the stability and physical properties of a fully human antibody in aqueous and solid forms. Pharm. Res. 2003, 20, 1952-1960.

103. Paborji, M.; Pochopin, N.L.; Coppola, W.P.; Bogardus, J.B. Chemical and physical stability of chimeric L6, a mouse-human monoclonal antibody. Pharm. Res. 1994, 11, 764-771.

104. McIntosh, K.A.; Charman, W.N.; Charman, S.A. The application of capillary electrophoresis for monitoring effects of excipients on protein conformation. J. Pharm. Biomed. Anal. 1998, 16, 1097-1105.

105. Li, S.; Patapoff, T.W.; Nguyen, T.H.; Borchardt, R.T. Inhibitory effect of sugars and polyols on the metal-catalyzed oxidation of human relaxin. J. Pharm. Sci. 1996, 85, 868-872.

106. Li, S.; Patapoff, T.W.; Overcashier, D.; Hsu, C.; Nguyen, T.H.; Borchardt, R.T. Effects of reducing sugars on the chemical stability of human relaxin in the lyophilized state. J. Pharm. Sci. 1996, 85, 873-877.

107. Ji, J.A.; Zhang, B.; Cheng, W.; John Wang, Y. Methionine, tryptophan, and histidine oxidation in a model protein, PTH: Mechanisms and stabilization. J. Pharm. Sci. 2009, 98, 4485-4500.

108. Gokarn, Y.R.; Matthew Fesinmeyer, R.; Saluja, A.; Razinkov, V.; Chase, S.F.; Laue, T.M.; Brems, D.N. Effective charge measurements reveal selective and preferential accumulation of anions, but not cations, at the protein surface in dilute salt solutions. Protein Sci. 2011, 20, 580-587.

109. Fesinmeyer, R.M.; Hogan, S.; Saluja, A.; Brych, S.R.; Kras, E.; Narhi, L.O.; Brems, D.N.; Gokarn, Y.R. Effect of ions on agitation- and temperature-induced aggregation reactions of antibodies. Pharm. Res. 2009, 26, 903-913.

110. Laue, T. Proximity energies: A framework for understanding concentrated solutions. J. Mol. Recognit. 2012, 25, 165-173.

111. Adams, G.P.; Schier, R.; McCall, A.M.; Crawford, R.S.; Wolf, E.J.; Weiner, L.M.; Marks, J.D. Prolonged in vivo tumour retention of a human diabody targeting the extracellular domain of human HER2/neu. Br. J. Cancer 1998, 77, 1405-1412.

112. Di Fede, G.; Bronte, G.; Rizzo, S.; Cervetto, C.R.; Cocorullo, G.; Gulotta, G.; Bazan, V.; Russo, A. Monoclonal antibodies and antibody fragments: State of the art and future perspectives in the treatment of non-haematological tumors. Expert Opin. Biol. Ther. 2011, 11, 1433-1445.

113. Stockwin, L.H.; Holmes, S. Antibodies as therapeutic agents: Vive la renaissance! Expert Opin. Biol. Ther. 2003, 3, 1133-1152.

114. Bookbinder, L.H.; Hofera, A.; Hallera, M.F.; Zepedab, M.L.; Kellera, G.-A.; Lima, J.E.; Edgingtonc, T.S.; Shepardd, H.M.; Pattone, J.S.; Frosta, G.I. A recombinant human enzyme for enhanced interstitial transport of therapeutics. J. Control Release 2006, 114, 230-241. 
115. Gatlin, L.A.; Gatlin, C.A.B. Formulation and administration techniques to minimize injection pain and tissue damage associated with parenteral products. In Injectable Drug Development: Techniques to Reduce Pain and Irritation; Gapta, P.K., Brazeau, G.A., Eds.; Interpharm Press: Denver, CO, USA, 1999; pp. 401-425.

116. Yu, A.W.; Leung, C.B.; Li, P.K.; Lui, S.F.; Lai, K.N. Pain perception following subcutaneous injections of citrate-buffered and phosphate-buffered epoetin alpha. Int. J. Artif. Organs. 1998, $21,41-43$.

117. Kappelgaard, A.M.; Bojesen, A.; Skydsgaard, K.; Sjögren, I.; Laursen, T. Liquid growth hormone: Preservatives and buffers. Horm. Res. 2004, 62, 98-103.

118. Laursen, T.; Hansen, B.; Fisker, S. Pain perception after subcutaneous injections of media containing different buffers. Basic Clin. Pharmacol. Toxicol. 2006, 98, 218-221.

119. Hall, D.; Minton, A.P. Macromolecular crowding: Qualitative and semiquantitative successes, quantitative challenges. Biochim. Biophys. Acta 2003, 1649, 127-139.

120. Rivas, G.; Minton, A.P. Non-ideal tracer sedimentation equilibrium: A powerful tool for the characterization of macromolecular interactions in crowded solutions. J. Mol. Recognit. 2004, 17, 362-367.

121. Yadav, S.; Laue, T.M.; Kalonia, D.S.; Singh, S.N.; Shire, S.J. The influence of charge distribution on self-association and viscosity behavior of monoclonal antibody solutions. Mol. Pharm. 2012, 9, 791-802.

122. Schein, C.H. Solubility as a function of protein structure and solvent components. Biotechnology 1990, 8, 308-317.

123. Shire, S.J.; Shahrokh, Z.; Liu, J. Challenges in the development of high protein concentration formulations. J. Pharm. Sci. 2004, 93, 1390-1402.

124. Sukumar, M.; Doyle, B.L.; Combs, J.L.; Pekar, A.H. Opalescent appearance of an IgG1 antibody at high concentrations and its relationship to noncovalent association. Pharm. Res. 2004, 21, 1087-1093.

125. Cromwell, M.E.M.; Carpenter, J.F.; Scherer, T.; Randolph, T.J. Opalescence in Antibody Formulations is a Solution Critical Phenomenon. In Proceseedings of the 236th ACS National Meeting, Philadelphia, PA, USA, 2008.

126. Saluja, A.; Kalonia, D.S. Nature and consequences of protein-protein interactions in high protein concentration solutions. Int. J. Pharm. 2008, 358, 1-15.

127. Zhou, H.X.; Rivas, G.; Minton, A.P. Macromolecular crowding and confinement: Biochemical, biophysical, and potential physiological consequences. Annu. Rev. Biophys. 2008, 37, 375-397.

128. Shiloach, J.; Martin, N.; Moes, H. Tangential flow filtration. Adv. Biotechnol. Processes. 1988, 8 , 97-125.

129. Shire, S.J.; Liu, J.; Friess, W.; Jörg, S.; Mahler, H.-C. High-concentration antibody formulations. In Formulation and Process Development Strategies for Manufacturing Biopharmaceuticals; Hershenson, F.J.S., Ed.; John Wiley \& Sons, Inc: Hoboken, NJ, USA, 2010.

130. Friess, H.; Langrehr, J.M.; Oettle, H.; Raedle, J.; Niedergethmann, M.; Dittrich, C.; Hossfeld, D.K.; Stöger, H.; Neyns, B.; Herzog, P.; et al. A randomized multi-center phase II trial of the angiogenesis inhibitor Cilengitide (EMD 121974) and gemcitabine compared with gemcitabine alone in advanced unresectable pancreatic cancer. BMC Cancer 2006, 6, 285. 
131. Rathore, N.; Pranay, P.; Bernacki, J.; Eu, B.; Ji, W.; Walls, E. Characterization of protein rheology and delivery forces for combination products. J. Pharm. Sci. 2012, 101, 4472-4480.

132. Harris, R.J.; Shire, S.J.; Winter, C. Commercial manufacturing scale formulation and analytical characterization of therapeutic recombinant antibodies. Drug Develop. Res. 2004, 61, 137-154.

133. Jimenez, M.; Rivas, G.; Minton, A.P. Quantitative characterization of weak self-association in concentrated solutions of immunoglobulin $G$ via the measurement of sedimentation equilibrium and osmotic pressure. Biochemistry 2007, 46, 8373-8378.

134. Minton, A.P. Analytical centrifugation with preparative ultracentrifuges. Anal. Biochem. 1989, 176, 209-216.

135. Kroe, R.R.; Laue, T.M. NUTS and BOLTS: Applications of fluorescence-detected sedimentation. Anal. Biochem. 2009, 390, 1-13.

136. MacGregor, I.K.; Anderson, A.L.; Laue, T.M. Fluorescence detection for the XLI analytical ultracentrifuge. Biophys. Chem. 2004, 108, 165-185.

137. Scherer, T.; Kanai, S.; Liu, J.; Shire, S. Characterization of monoclonal antibodies at high concentrations by light scattering. In Proceedings of AAPS National Biotechnology Conference, San Diego, CA, USA, 2007.

138. Ross, P.D.; Minton, A.P. Analysis of non-ideal behavior in concentrated hemoglobin solutions. J. Mol. Biol. 1977, 112, 437-452.

139. Yousef, M.A.; Datta, R.; Rodgers, V.G.J. Free-Solvent Model of Osmotic Pressure Revisited: Application to Concentrated IgG Solution under Physiological Conditions. J. Colloid. Interface Sci. 1998, 197, 108-118.

140. Paliwal, A.; Asthagiri, D.; Abras, D.; Lenhoff, A.M.; Paulaitis, M.E. Light-scattering studies of protein solutions: Role of hydration in weak protein-protein interactions. Biophys. J. 2005, 89, 1564-1573.

141. Neal, B.L.; Asthagiri, D.; Lenhoff, A.M. Molecular origins of osmotic second virial coefficients of proteins. Biophys. J. 1998, 75, 2469-2477.

142. Salinas, B.A.; Sathish, H.A.; Bishop, S.M.; Harn, N.; Carpenter, J.F.; Randolph, T.W. Understanding and modulating opalescence and viscosity in a monoclonal antibody formulation. J. Pharm. Sci. 2010, 99, 82-93.

143. Saito, S.; Hasegawa, J.; Kobayashi, N.; Kishi, N.; Uchiyama, S.; Fukui, K. Behavior of monoclonal antibodies: Relation between the second virial coefficient (B (2)) at low concentrations and aggregation propensity and viscosity at high concentrations. Pharm. Res. 2012, 29, 397-410.

144. Attri, A.K.; Minton, A.P. New methods for measuring macromolecular interactions in solution via static light scattering: Basic methodology and application to nonassociating and self-associating proteins. Anal. Biochem. 2005, 337, 103-110.

145. Alford, J.R.; Kendrick, B.S.; Carpenter, J.F.; Randolph, T.W. Measurement of the second osmotic virial coefficient for protein solutions exhibiting monomer-dimer equilibrium. Anal. Biochem. 2008, 377, 128-133.

146. Some, D.; Kenrick, S. Characterization of protein-protein interactions via static and dynamic light scattering, in rotein interaction. In Protein Interactions; Cai, J., Ed.; InTech.: Rijeka, Croatia, 2012. 
147. Le Brun, V.; Friess, W.; Bassarab, S.; Garidel, P. Correlation of protein-protein interactions as assessed by affinity chromatography with colloidal protein stability: A case study with lysozyme. Pharm. Dev. Technol. 2010, 15, 421-430.

148. Le Brun, V.; Friess, W.; Bassarab, S.; Mühlau, S.; Garidel, P. A critical evaluation of selfinteraction chromatography as a predictive tool for the assessment of protein-protein interactions in protein formulation development: A case study of a therapeutic monoclonal antibody. Eur. J. Pharm. Biopharm. 2010, 75, 16-25.

149. Deszczynski, M.; Harding, S.E.; Winzor, D.J. Negative second virial coefficients as predictors of protein crystal growth: Evidence from sedimentation equilibrium studies that refutes the designation of those light scattering parameters as osmotic virial coefficients. Biophys. Chem. 2006, 120, 106-113.

150. Tessier, P.M.; Lenhoff, A.M.; Sandler, S.I. Rapid measurement of protein osmotic second virial coefficients by self-interaction chromatography. Biophys. J. 2002, 82, 1620-1631.

151. Saluja, A.; Matthew Fesinmeyer, R.; Hogan, S.; Brems, D.N. Diffusion and sedimentation interaction parameters for measuring the second virial coefficient and their utility as predictors of protein aggregation. Biophys. J. 2010, 99, 2657-2665.

152. Harding, S.E.; Johnson, P. The concentration-dependence of macromolecular parameters. Biochem. J. 1985, 231, 543-547.

153. Connolly, B.D.; Petry, C.; Yadav, S.; Demeule, B.; Ciaccio, N.; Moore, J.M.R.; Shire, S.J.; Gokarn, Y.R. Weak interactions govern the viscosity of concentrated antibody solutions: High-throughput analysis using the diffusion interaction parameter. Biophys. J. 2012, 103, 69-78.

154. Winzor, D.J.; Jones, S.; Harding, S.E. Determination of protein charge by capillary zone electrophoresis. Anal. Biochem. 2004, 333, 225-229.

155. Durant, J.A.; Chen, C.; Laue, T.M.; Moody, T.P.; Allison, S.A. Use of T4 lysozyme charge mutants to examine electrophoretic models. Biophys. Chem. 2002, 101-102, 593-609.

156. WYATT. Available online: www.wyatt.com (accessed on 1 June 2013).

157. Minton, A.P. Molecular crowding: Analysis of effects of high concentrations of inert cosolutes on biochemical equilibria and rates in terms of volume exclusion. Methods Enzymol. 1998, 295, 127-149.

158. Janthur, W.-D.; Cantoni, N.; Mamot, C. Drug Conjugates Such as Antibody Drug Conjugates (ADCs), Immunotoxins and Immunoliposomes Challenge Daily Clinical Practice. Int. J. Mol. Sci. 2012, 13, 16020-16045.

159. Adair, J.R.; Howard, P.W.; Hartley, J.A.; Williams, D.G.; Chester, K.A. Antibody-drug conjugates-A perfect synergy. Expert Opin. Biol. Ther. 2012, 12, 1191-1206.

160. Sievers, E.L.; Senter, P.D. Antibody-drug conjugates in cancer therapy. Annu. Rev. Med. 2013, $64,15-29$.

161. Sutherland, M.S.; Sanderson, R.J.; Gordon, K.A.; Andreyka, J.; Cerveny, C.G.; Yu, C.; Lewis, T.S.; Meyer, D.L.; Zabinski, R.F.; Doronina, S.O.; et al. Lysosomal trafficking and cysteine protease metabolism confer target-specific cytotoxicity by peptide-linked anti-CD30-auristatin conjugates. J. Biol. Chem. 2006, 281, 10540-10547. 
162. Okeley, N.M.; Miyamoto, J.B.; Zhang, X.; Sanderson, R.J.; Benjamin, D.R.; Sievers, E.L.; Senter, P.D.; Alley, S.C. Intracellular activation of SGN-35, a potent anti-CD30 antibody-drug conjugate. Clin. Cancer Res. 2010, 16, 888-897.

163. Lam, K.C.L.; Rajaraman, G. Assessment of P-glycoprotein substrate and inhibition potential of test compounds in MDR1-transfected MDCK cells. Curr. Protoc. Pharmacol. 2012, doi: 10.1002/0471141755.ph0713s58.

164. Krech, T.; Scheuerera, E.; Geffers, R.; Kreipe, H.; Lehmann, U.; Christgen, M. ABCB1/MDR1 contributes to the anticancer drug-resistant phenotype of IPH-926 human lobular breast cancer cells. Cancer Lett. 2012, 315, 153-160.

165. Bidwell, G.L., 3rd; Davis, A.N.; Fokt, I.; Priebe, W.; Raucher, D. A thermally targeted elastinlike polypeptide-doxorubicin conjugate overcomes drug resistance. Invest. New Drugs 2007, 25, 313-326.

166. Hughes, B. Antibody-drug conjugates for cancer: Poised to deliver? Nat. Rev. Drug Discov. 2010, 9, 665-667.

167. Barginear, M.F.; John, V.; Budman, D.R. Trastuzumab-DM1: A clinical update of the novel antibody-drug conjugate for HER2-overexpressing breast cancer. Mol. Med. 2013, 18, 1473-1479.

168. Rowland, G.F.; O'Neill, G.J.; Davies, D.A. Suppression of tumour growth in mice by a drug-antibody conjugate using a novel approach to linkage. Nature 1975, 255, 487-488.

169. Beck, A.; Lambert, J.; Sun, M.; Lin, K. Fourth World Antibody-Drug Conjugate Summit: February 29-March 1, 2012, Frankfurt, Germany. MAbs 2012, 4, 637-647.

170. Xie, H.; Audette, C.; Hoffee, M.; Lambert, J.M.; Blättler, W.A. Pharmacokinetics and biodistribution of the antitumor immunoconjugate, cantuzumab mertansine (huC242-DM1), and its two components in mice. J. Pharmacol. Exp. Ther. 2004, 308, 1073-1082.

171. Ducry, L.; Stump, B. Antibody-drug conjugates: Linking cytotoxic payloads to monoclonal antibodies. Bioconjug. Chem. 2010, 21, 5-13.

172. Dosio, F.; Brusa, P.; Cattel, L. Immunotoxins and anticancer drug conjugate assemblies: The role of the linkage between components. Toxins (Basel) 2011, 3, 848-883.

173. Hamblett, K.J.; Senter, P.D.; Chace, D.F.; Sun, M.M.C.; Lenox, J.; Cerveny, C.G.; Kissler, K.M.; Bernhardt, S.X.; Kopcha, A.K.; Zabinski, R.F. Effects of drug loading on the antitumor activity of a monoclonal antibody drug conjugate. Clin. Cancer Res. 2004, 10, 7063-7070.

174. Le, L.N.; Moore, J.M.R.; Ouyang, J.; Chen, X.; Nguyen, M.D.H.; Galush, W.J. Profiling antibody drug conjugate positional isomers: A system-of-equations approach. Anal. Chem. 2012, 84, 7479-7486.

175. Liu, H.; Chumsae, C.; Gaza-Bulseco, G.; Hurkmans, K.; Radziejewski, C.H. Ranking the susceptibility of disulfide bonds in human IgG1 antibodies by reduction, differential alkylation, and LC-MS analysis. Anal. Chem. 2010, 82, 5219-5226.

176. Sun, M.M.; Beam, K.S.; Cerveny, C.G.; Hamblett, K.J.; Blackmore, R.S.; Torgov, M.Y.; Handley, F.G.M.; Ihle, N.C.; Senter, P.D.; Alley, S.C. Reduction-alkylation strategies for the modification of specific monoclonal antibody disulfides. Bioconjug. Chem. 2005, 16, 1282-1290.

177. Dornan, D.; Bennett, F.; Chen, Y.; Dennis, M.; Eaton, D.; Elkins, K.; French, D.; Go, M.A.T.; Jack, A.; Junutula, J.R.; et al. Therapeutic potential of an anti-CD79b antibody-drug conjugate, anti-CD79b-vc-MMAE, for the treatment of non-Hodgkin lymphoma. Blood 2009, 114, 2721-2729. 
178. Junutula, J.R.; Raab, H.; Clark, S.; Bhakta, S.; Leipold, D.D.; Weir, S.; Chen, Y.; Simpson, M.; Tsai, S.P.; Dennis, M.S.; et al. Site-specific conjugation of a cytotoxic drug to an antibody improves the therapeutic index. Nat. Biotechnol. 2008, 26, 925-932.

179. Shen, B.Q.; Xu, K.; Liu, L.; Raab, H.; Bhakta, S.; Kenrick, M.; Parsons-Reponte, K.L.; Tien, J.; $\mathrm{Yu}, \mathrm{S} .-\mathrm{F} . ; \mathrm{Mai}, \mathrm{E}$; et al. Conjugation site modulates the in vivo stability and therapeutic activity of antibody-drug conjugates. Nat. Biotechnol. 2012, 30, 184-189.

180. Axup, J.Y.; Bajjuri, K.M.; Ritland, M.; Hutchinsa, B.M.; Kima, C.H.; Kazane, S.A.; Halder, R.; Forsyth, J.S.; Santidrian, A.F.; Stafin, K.; et al. Synthesis of site-specific antibody-drug conjugates using unnatural amino acids. Proc. Natl. Acad. Sci. USA 2012, 109, 16101-16106.

181. Presentini, R.; Terrana, B. Influence of the antibody-peroxidase coupling methods on the conjugate stability and on the methodologies for the preservation of the activity in time. J. Immunoassay 1995, 16, 309-324.

182. Fishkin, N.; Maloney, E.K.; Chari, R.V.J.; Singh, R. A novel pathway for maytansinoid release from thioether linked antibody-drug conjugates (ADCs) under oxidative conditions. Chem. Commun. (Camb) 2011, 47, 10752-10754.

183. Ryan, C.P.; Smith, M.E.B.; Schumacher, F.F.; Grohmann, D.; Papaioannou, D.; Waksman, G.; Werner, F.; Baker, J.R.; Caddick, S. Tunable reagents for multi-functional bioconjugation: Reversible or permanent chemical modification of proteins and peptides by control of maleimide hydrolysis. Chem. Commun. (Camb) 2011, 47, 5452-5454.

184. Doronina, S.O.; Mendelsohn, B.A.; Bovee, T.D.; Cerveny, C.G.; Alley, S.C.; Meyer, D.L.; Oflazoglu, E.; Toki, B.E.; Sanderson, R.J.; Zabinski, R.F.; et al. Enhanced activity of monomethylauristatin $\mathrm{F}$ through monoclonal antibody delivery: Effects of linker technology on efficacy and toxicity. Bioconjug. Chem. 2006, 17, 114-124.

185. Dubowchik, G.M.; Radia, S.; Mastalerz, H.; Walker, M.A.; Firestone, R.A.; Dalton King, H.; Hofstead, S.J.; Willner, D.; Lasch, S.J.; Trail, P.A. Doxorubicin immunoconjugates containing bivalent, lysosomally-cleavable dipeptide linkages. Bioorg. Med. Chem. Lett. 2002, 12, 1529-1532.

186. Sapra, P.; Damelin, M.; DiJoseph, J.; Marquette, K.; Geles, K.G.; Golas, J.; Dougher, M.; Narayanan, B.; Giannakou, A.; Khandke, K.; et al. Long-term tumor regression induced by an antibody-drug conjugate that targets 5T4, an oncofetal antigen expressed on tumor-initiating cells. Mol. Cancer Ther. 2013, 12, 38-47.

187. Polson, A.G.; Calemine-Fenaux, J.; Chan, P.; Chang, W.; Christensen, E.; Clark, S.; de Sauvage, F.J.; Eaton, D.; Elkins, K.; Michael Elliott, J.; et al. Antibody-drug conjugates for the treatment of non-Hodgkin's lymphoma: Target and linker-drug selection. Cancer Res. 2009, 69, 2358-2364.

188. Erickson, H.K.; Park, P.U.; Widdison, W.C.; Kovtun, Y.V.; Garrett, L.M.; Hoffman, K.; Lutz, R.J.; Goldmacher, V.S.; Blättler, W.A. Antibody-maytansinoid conjugates are activated in targeted cancer cells by lysosomal degradation and linker-dependent intracellular processing. Cancer Res. 2006, 66, 4426-4433.

189. Oflazoglu, E.; Stone, I.J.; Gordon, K.; Wood, C.G.; Repasky, E.A.; Grewal, I.S.; Law, C.-L.; Gerber, H.-P. Potent anticarcinoma activity of the humanized anti-CD70 antibody h1F6 conjugated to the tubulin inhibitor auristatin via an uncleavable linker. Clin. Cancer Res. 2008, 14, 6171-6180. 
190. Hollander, I.; Kunz, A.; Hamann, P.R. Selection of reaction additives used in the preparation of monomeric antibody-calicheamicin conjugates. Bioconjug. Chem. 2008, 19, 358-361.

191. Wakankar, A.A.; Feeney, M.B.; Rivera, J.; Chen, Y.; Kim, M.; Sharma, V.K.; John Wang, Y. Physicochemical stability of the antibody-drug conjugate Trastuzumab-DM1: Changes due to modification and conjugation processes. Bioconjug. Chem. 2010, 21, 1588-1595.

192. Quiles, S.; Raisch, K.P.; Sanford, L.L.; Bonner, J.A.; Safavy, A. Synthesis and preliminary biological evaluation of high-drug-load paclitaxel-antibody conjugates for tumor-targeted chemotherapy. J. Med. Chem. 2010, 53, 586-594.

193. King, H.D.; Yurgaitis, D.; Willner, D.; Firestone, R.A.; Yang, M.B.; Lasch, S.J.; Hellström, K.E.; Trail, P.A. Monoclonal antibody conjugates of doxorubicin prepared with branched peptide linkers: Inhibition of aggregation by methoxytriethyleneglycol chains. J. Med. Chem. 2002, 45, 4336-4343.

194. Kafi, K.; Betting, D.J.; Yamada, R.E.; Bacica, M.; Steward, K.K.; Timmerman, J.M. Maleimide conjugation markedly enhances the immunogenicity of both human and murine idiotype-KLH vaccines. Mol. Immunol. 2009, 46, 448-456.

195. Christie, R.J.; Anderson, D.J.; Grainger, D.W. Comparison of hydrazone heterobifunctional cross-linking agents for reversible conjugation of thiol-containing chemistry. Bioconjug. Chem. 2010, 21, 1779-1787.

196. Bagshawe, K.D. Targeting: The ADEPT story so far. Curr. Drug Targets 2009, 10, 152-157.

197. Pastan, I.; Hassan, R.; FitzGerald, D.J.; Kreitman, R.J. Immunotoxin treatment of cancer. Annu. Rev. Med. 2007, 58, 221-237.

198. Vogelzang, N.J.; Porta, C.; Mutti, L. New agents in the management of advanced mesothelioma. Semin. Oncol. 2005, 32, 336-350.

199. Pavlakis, N.; Vogelzang, N.J. Ranpirnase-An antitumour ribonuclease: Its potential role in malignant mesothelioma. Expert Opin. Biol. Ther. 2006, 6, 391-399.

200. Rosenblum, M.G.; Barth, S. Development of novel, highly cytotoxic fusion constructs containing granzyme B: Unique mechanisms and functions. Curr. Pharm. Des. 2009, 15, 2676-2692.

201. Kurschus, F.C.; Kleinschmidt, M.; Fellows, E.; Dornmair, K.; Rudolph, R.; Lilie, H.; Jenne, D.E. Killing of target cells by redirected granzyme B in the absence of perforin. FEBS Lett. 2004, 562, 87-92.

202. Weidle, U.H.; Georges, G.; Brinkmann, U. Fully human targeted cytotoxic fusion proteins: New anticancer agents on the horizon. Cancer Genomics Proteomics 2012, 9, 119-133.

203. Larrick, J.W.; Cresswell, P. Modulation of cell surface iron transferrin receptors by cellular density and state of activation. J. Supramol. Struct. 1979, 11, 579-586.

204. Kordower, J.H.; Charles, V.; Bayer, R.; Bartus, R.T.; Putney, S.; Walus, L.R.; Friden, P.M. Intravenous administration of a transferrin receptor antibody-nerve growth factor conjugate prevents the degeneration of cholinergic striatal neurons in a model of Huntington disease. Proc. Natl. Acad. Sci. USA 1994, 91, 9077-9080.

205. Granholm, A.C.; Albeck, D.; Bäckman, C.; Curtis, M.; Ebendal, T.; Friden, P.; Henry, M.; Hoffer, B.; Kordower, J.; Rose, G.M.; et al. A non-invasive system for delivering neural growth factors across the blood-brain barrier: A review. Rev. Neurosci. 1998, 9, 31-55. 
206. McGrath, J.P.; Cao, X.; Schutz, A.; Lynch, P.; Ebendal, T.; Josephina Coloma, M.; Morrison, S.L.; Putney, S.D. Bifunctional fusion between nerve growth factor and a transferrin receptor antibody. J. Neurosci. Res. 1997, 47, 123-133.

207. Penichet, M.L.; Kang, Y.-S.; Pardridge, W.M.; Morrison, S.L.; Shin, S.-U. An antibody-avidin fusion protein specific for the transferrin receptor serves as a delivery vehicle for effective brain targeting: Initial applications in anti-HIV antisense drug delivery to the brain. J. Immunol. 1999, 163, 4421-4426.

208. Ng, P.P.; Dela Cruz, J.S.; Sorour, D.N.; Stinebaugh, J.M.; Shin, S.-U.; Shin, D.S.; Morrison, S.L.; Penichet, M.L. An anti-transferrin receptor-avidin fusion protein exhibits both strong proapoptotic activity and the ability to deliver various molecules into cancer cells. Proc. Natl. Acad. Sci. USA 2002, 99, 10706-10711.

209. Xuan, C.; Steward, K.K.; Timmerman, J.M.; Morrison, S.L. Targeted delivery of interferonalpha via fusion to anti-CD20 results in potent antitumor activity against B-cell lymphoma. Blood 2010, 115, 2864-2871.

210. Koehn, T.A.; Trimble, L.L.; Alderson, K.L.; Erbe, A.K.; McDowell, K.A.; Grzywacz, B.; Hank, J.A.; Sondel, P.M. Increasing the clinical efficacy of NK and antibody-mediated cancer immunotherapy: Potential predictors of successful clinical outcome based on observations in high-risk neuroblastoma. Front. Pharmacol. 2012, 3, 91.

211. Lode, H.N.; Xiang, R.; Becker, J.C.; Gillies, S.D.; Reisfel, R.A. Immunocytokines: A promising approach to cancer immunotherapy. Pharmacol. Ther. 1998, 80, 277-292.

212. Johnson, E.; Dean, S.M.; Sondel, P.M. Antibody-based immunotherapy in high-risk neuroblastoma. Expert Rev. Mol. Med. 2007, 9, 1-21.

213. Dela Cruz, J.S.; Ryan Trinh, K.; Morrison, S.L.; Penichet, M.L. Recombinant anti-human HER2/neu IgG3-(GM-CSF) fusion protein retains antigen specificity and cytokine function and demonstrates antitumor activity. J. Immunol. 2000, 165, 5112-5121.

214. Cho, H.M.; Rosenblatt, J.D.; Kang, Y.-S.; Luisa Iruela-Arispe, M.; Morrison, S.L.; Penichet, M.L.; Kwon, Y.-G.; Kim, T.-W.; Webster, K.A.; Nechustan, H. Enhanced inhibition of murine tumor and human breast tumor xenografts using targeted delivery of an antibody-endostatin fusion protein. Mol. Cancer Ther. 2005, 4, 956-967.

215. Zhang, H.; Lu, S.; Morrison, S.L.; Tomlinson, S. Targeting of functional antibody-decayaccelerating factor fusion proteins to a cell surface. J. Biol. Chem. 2001, 276, 27290-27295.

216. Fung, V.P. Method for producing recombinant proteins. US Patent 7,294,481, 2007.

217. Sassenfeld, H.M.; Remmele, R.L., Jr.; McCoy, R.E. Increased recovery of active proteins, US Patent 7,157,55, 2007.

218. Bouchon, A.; Facchetti, F.; Weigand, M.A.; Colonna, M. TREM-1 amplifies inflammation and is a crucial mediator of septic shock. Nature 2001, 410, 1103-1107.

219. Iwai, H.; Kohsaka, H. Blockade of Triggering receptor expressed on myeloid cells-1 as a new therapy of arthritis. Nihon Rinsho Meneki Gakkai Kaishi 2012, 35, 81-86.

220. Holash, J.; Davis, S.; Papadopoulos, N.; Croll, S.D.; Ho, L.; Russell, M.; Boland, P.; Leidich, R.; Hylton, D.; Burova, E.; et al. VEGF-Trap: A VEGF blocker with potent antitumor effects. Proc. Natl. Acad. Sci. USA 2002, 99, 11393-11398. 
221. Peters, R.T.; Low, S.C.; Kamphaus, G.D.; Dumont, J.A.; Amari, J.V.; Lu, Q.; Zarbis-Papastoitsis, G.; Reidy, T.J.; Merricks, E.P.; Nichols, T.C.; et al. Prolonged activity of factor IX as a monomeric Fc fusion protein. Blood 2010, 115, 2057-2064.

222. Hall, M.P.; Gegg, C.; Walker, K.; Spahr, C.; Ortiz, R.; Patel, V.; Yu, S.; Zhang, L.; Lu, H.; DeSilva, B.; et al. Ligand-binding mass spectrometry to study biotransformation of fusion protein drugs and guide immunoassay development: Strategic approach and application to peptibodies targeting the thrombopoietin receptor. AAPS J. 2010, 12, 576-585.

223. Gokarn, Y.R.; Matthew Fesinmeyer, R.; Saluja, A.; Cao, S.; Dankberg, J.; Goetze, A.; Remmele, R.L., Jr.; Narhi, L.O.; Brems, D.N. Ion-specific modulation of protein interactions: Anioninduced, reversible oligomerization of a fusion protein. Protein Sci. 2009, 18, 169-179.

224. Nisonoff, A.; Rivers, M.M. Recombination of a mixture of univalent antibody fragments of different specificity. Arch. Biochem. Biophys. 1961, 93, 460-462.

225. May, C.; Sapra, P.; Gerber, H.P. Advances in bispecific biotherapeutics for the treatment of cancer. Biochem. Pharmacol. 2012, 84, 1105-1112.

226. Scott, A.M.; Wolchok, J.D.; Old, L.J. Antibody therapy of cancer. Nat. Rev. Cancer 2012, 12, 278-287.

227. Vallera, D.A.; Todhunter, D.A.; Kuroki, D.W.; Shu, Y.; Sicheneder, A.; Chen, H. A bispecific recombinant immunotoxin, DT2219, targeting human CD19 and CD22 receptors in a mouse xenograft model of B-cell leukemia/lymphoma. Clin. Cancer Res. 2005, 11, 3879-3888.

228. Dorvillius, M.; Garambois, V.; Pourquier, D.; Gutowski, M.; Rouanet, P.; Mani, J.-C.; Pugnière, M.; Hynes, N.E.; Pèlegrin, A. Targeting of human breast cancer by a bispecific antibody directed against two tumour-associated antigens: ErbB-2 and carcinoembryonic antigen. Tumour Biol. 2002, 23, 337-347.

229. Jimenez, X.; Lu, D.; Brennan, L.; Persaud, K.; Liu, M.; Miao, H.; Witte, L.; Zhu, Z. A recombinant, fully human, bispecific antibody neutralizes the biological activities mediated by both vascular endothelial growth factor receptors 2 and 3. Mol. Cancer Ther. 2005, 4, 427-434.

230. Lu, D.; Zhang, H.; Koo, H.; Tonra, J.; Balderes, P.; Prewett, M.; Corcoran, E.; Mangalampalli, V.; Bassi, R.; Anselma, D.; et al. A fully human recombinant IgG-like bispecific antibody to both the epidermal growth factor receptor and the insulin-like growth factor receptor for enhanced antitumor activity. J. Biol. Chem. 2005, 280, 19665-19672.

231. Tanaka, K.; Isselbacher, K.J.; Khoury, G.; Jay, G. Reversal of oncogenesis by the expression of a major histocompatibility complex class I gene. Science 1985, 228, 26-30.

232. Hartmann, F.; Renner, C.; Jung, W.; Deisting, C.; Juwana, M.; Eichentopf, B.; Kloft, M.; Pfreundschuh, M. Treatment of refractory Hodgkin's disease with an anti-CD16/CD30 bispecific antibody. Blood 1997, 89, 2042-2047.

233. Taylor, R.P.; Sutherland, W.M.; Martin, E.N.; Ferguson, P.J.; Reinagel, M.L.; Gilbert, E.; Lopez, K.; Incardona, N.L.; Ochs, H.D. Bispecific monoclonal antibody complexes bound to primate erythrocyte complement receptor 1 facilitate virus clearance in a monkey model. J. Immunol. 1997, 158, 842-850.

234. Reinagel, M.L.; Taylor, R.P. Transfer of immune complexes from erythrocyte CR1 to mouse macrophages. J. Immunol. 2000, 164, 1977-1985. 
235. French, R.R.; Penney, C.A.; Browning, A.C.; Stirpe, F.; George, A.J.; Glennie, M.J. Delivery of the ribosome-inactivating protein, gelonin, to lymphoma cells via CD22 and CD38 using bispecific antibodies. Br. J. Cancer 1995, 71, 986-994.

236. Ford, C.H.; Osborne, P.A.; Rego, B.G.; Mathew, A. Bispecific antibody targeting of doxorubicin to carcinoembryonic antigen-expressing colon cancer cell lines in vitro and in vivo. Int. J. Cancer 2001, 92, 851-855.

237. Zhu, H.; Jain, R.K.; Baxter, L.T. Tumor pretargeting for radioimmunodetection and radioimmunotherapy. J. Nucl. Med. 1998, 39, 65-76.

238. Kipriyanov, S.M.; Le Gall, F. Recent advances in the generation of bispecific antibodies for tumor immunotherapy. Curr. Opin. Drug Discov. Develop. 2004, 7, 233-242.

239. Mack, M.; Riethmuller, G.; Kufer, P. A small bispecific antibody construct expressed as a functional single-chain molecule with high tumor cell cytotoxicity. Proc. Natl. Acad. Sci. USA 1995, 92, 7021-7025.

240. Mack, M.; Gruber, R.; Schmidt, S.; Riethmüller, G.; Kufer, P. Biologic properties of a bispecific single-chain antibody directed against 17-1A (EpCAM) and CD3: Tumor cell-dependent $\mathrm{T}$ cell stimulation and cytotoxic activity. J. Immunol. 1997, 158, 3965-39670.

241. Milstein, C.; Cuello, A.C. Hybrid hybridomas and their use in immunohistochemistry. Nature 1983, 305, 537-540.

242. Staerz, U.D.; Bevan, M.J. Hybrid hybridoma producing a bispecific monoclonal antibody that can focus effector T-cell activity. Proc. Natl. Acad. Sci. USA 1986, 83, 1453-1457.

243. Lindhofer, H.; Mocikat, R.; Steipe, B.; Thierfelder, S. Preferential species-restricted heavy/light chain pairing in rat/mouse quadromas. Implications for a single-step purification of bispecific antibodies. J. Immunol. 1995, 155, 219-225.

244. Brennan, M.; Davison, P.F.; Paulus, H. Preparation of bispecific antibodies by chemical recombination of monoclonal immunoglobulin G1 fragments. Science 1985, 229, 81-83.

245. Merchant, A.M.; Zhu, Z.; Yuan, J.Q.; Goddard, A.; Adams, C.W.; Presta, L.G.; Carter, P. An efficient route to human bispecific IgG. Nat. Biotechnol. 1998, 16, 677-681.

246. Ridgway, J.B.; Presta, L.G.; Carter, P. 'Knobs-into-holes' engineering of antibody CH3 domains for heavy chain heterodimerization. Protein Eng. 1996, 9, 617-621.

247. Davis, J.H.; Aperlo, C.; Li, Y.; Kurosawa, E.; Lan, Y.; Lo, K.-M.; Huston, J.S. SEEDbodies: Fusion proteins based on strand-exchange engineered domain (SEED) $\mathrm{CH} 3$ heterodimers in an Fc analogue platform for asymmetric binders or immunofusions and bispecific antibodies. Protein Eng. Des. Sel. 2010, 23, 195-202.

248. Holliger, P.; Prospero, T.; Winter, G. "Diabodies": Small bivalent and bispecific antibody fragments. Proc. Natl. Acad. Sci. USA 1993, 90, 6444-6448.

249. Kipriyanov, S.M.; Moldenhauer, G.; Schuhmacher, J.; Cochlovius, B.; Von der Lieth, C.-W.; Ronald Matys, E.; Little, M. Bispecific tandem diabody for tumor therapy with improved antigen binding and pharmacokinetics. J. Mol. Biol. 1999, 293, 41-56.

250. De Jonge, J.; Heirman, C.; de Veerman, M.; Van Meirvenne, S.; Moser, M.; Leo, O.; Thielemans, $\mathrm{K}$. In vivo retargeting of $\mathrm{T}$ cell effector function by recombinant bispecific single chain $\mathrm{Fv}$ (anti-CD3 $\mathrm{x}$ anti-idiotype) induces long-term survival in the murine BCL1 lymphoma model. J. Immunol. 1998, 161, 1454-1461. 
251. Kufer, P.; Lutterbuse, R.; Baeuerle, P.A. A revival of bispecific antibodies. Trends Biotechnol. 2004, 22, 238-244.

252. Topp, M.S.; Kufer, P.; Gökbuget, N.; Goebeler, M.; Klinger, M.; Neumann, S.; Horst, H.-A.; Raff, T.; Viardot, A.; Schmid, M.; et al. Targeted therapy with the T-cell-engaging antibody blinatumomab of chemotherapy-refractory minimal residual disease in B-lineage acute lymphoblastic leukemia patients results in high response rate and prolonged leukemia-free survival. J. Clin. Oncol. 2011, 29, 2493-2498.

253. Baeuerle, P.A.; Reinhardt, C. Bispecific T-cell engaging antibodies for cancer therapy. Cancer Res. 2009, 69, 4941-4944.

254. Johnson, S.; Burke, S.; Huang, L.; Gorlatov, S.; Li, H.; Wang, W.; Zhang, W.; Tuaillon, N.; Rainey, J.; Barat, B.; et al. Effector cell recruitment with novel Fv-based dual-affinity re-targeting protein leads to potent tumor cytolysis and in vivo B-cell depletion. J. Mol. Biol. 2010, 399, 436-449.

255. Moore, P.A.; Zhang, W.; Jonah Rainey, G.; Burke, S.; Li, H.; Huang, L.; Gorlatov, S.; Veri, M.C.; Aggarwal, S.; Yang, Y.; et al. Application of dual affinity retargeting molecules to achieve optimal redirected T-cell killing of B-cell lymphoma. Blood 2011, 117, 4542-4551.

256. Wu, C.; Ying, H.; Grinnell, C.; Bryant, S.; Miller, R.; Clabbers, A.; Bose, S.; McCarthy, D.; Zhu, R.-R.; Santora, L.; et al. Simultaneous targeting of multiple disease mediators by a dual-variabledomain immunoglobulin. Nat. Biotechnol. 2007, 25, 1290-1297.

257. F-star. Available online: www.f-star.com (accessed on 1 June 2013).

258. IMMUNOCORE. Available online:www.immunocore.com (accessed on 1 June 2013).

259. Hartmann, F.; Renner, C.; Jung, W.; da Costa, L.; Tembrink, S.; Held, G.; Sek, A.; König, J.; Bauer, S.; Kloft, M.; Pfreundschuh, M. Anti-CD16/CD30 bispecific antibody treatment for Hodgkin's disease: Role of infusion schedule and costimulation with cytokines. Clin. Cancer Res. 2001, 7, 1873-1881.

260. Schmitt, M.; Schmitt, A.; Reinhardt, P.; Thess, B.; Manfras, B.; Lindhofer, H.; Riechelmann, H.; Wiesneth, M.; Gronau, S. Opsonization with a trifunctional bispecific (alphaCD3 x alphaEpCAM) antibody results in efficient lysis in vitro and in vivo of EpCAM positive tumor cells by cytotoxic T lymphocytes. Int. J. Oncol. 2004, 25, 841-848.

261. Jager, M.; Schoberth, A.; Ruf, P.; Hess, J.; Hennig, M.; Schmalfeldt, B.; Wimberger, P.; Ströhlein, M.; Theissen, B.; Heiss, M.M.; et al. Immunomonitoring results of a phase II/III study of malignant ascites patients treated with the trifunctional antibody catumaxomab (anti-EpCAM $\mathrm{x}$ anti-CD3). Cancer Res. 2012, 72, 24-32.

262. Pluen, A.; Boucher, Y.; Ramanujan, S.; McKee, T.D.; Gohongi, T.; di Tomaso, E.; Brown, E.B.; Izumi, Y.; Campbell, R.B.; Berk, D.A.; et al. Role of tumor-host interactions in interstitial diffusion of macromolecules: Cranial vs. subcutaneous tumors. Proc. Natl. Acad. Sci. USA 2001, 98, 4628-4633.

263. Khawli, L.A.; Biela, B.; Hu, P.; Epstein, A.L. Comparison of recombinant derivatives of chimeric TNT-3 antibody for the radioimaging of solid tumors. Hybrid. Hybridomics 2003, 22, 1-9. 
264. Tahtis, K.; Lee, F.-T.; Smyth, F.E.; Power, B.E.; Renner, C.; Brechbiel, M.W.; Old, L.J.; Hudson, P.J.; Scott, A.M. Biodistribution properties of (111)indium-labeled C-functionalized transcyclohexyl diethylenetriaminepentaacetic acid humanized 3S193 diabody and $\mathrm{F}\left(\mathrm{ab} \mathrm{b}^{\prime}\right)(2)$ constructs in a breast carcinoma xenograft model. Clin. Cancer Res. 2001, 7, 1061-1072.

265. Thurber, G.M.; Wittrup, K.D. Quantitative spatiotemporal analysis of antibody fragment diffusion and endocytic consumption in tumor spheroids. Cancer Res. 2008, 68, 3334-3341.

266. Ottiger, M.; Thiel, M.A.; Feige, U.; Lichtlen, P.; Urech, D.M. Efficient intraocular penetration of topical anti-TNF-alpha single-chain antibody (ESBA105) to anterior and posterior segment without penetration enhancer. Invest. Ophthalmol. Vis. Sci. 2009, 50, 779-786.

267. Cardoso, R.M.; Zwick, M.B.; Stanfield, R.L.; Kunert, R.; Binley, J.M.; Katinger, H.; Burton, D.R. Broadly neutralizing anti-HIV antibody 4E10 recognizes a helical conformation of a highly conserved fusion-associated motif in gp41. Immunity 2005, 22, 163-173.

268. Stijlemans, B.; Wyns, L.; Senter, P.; Revets, H.; De Baetselier, P.; Muyldermans, S.; Magez, S. Efficient targeting of conserved cryptic epitopes of infectious agents by single domain antibodies. African trypanosomes as paradigm. J. Biol. Chem. 2004, 279, 1256-1261.

269. Nuttall, S.D.; Humberstone, K.S.; Krishnan, U.V.; Carmichael, J.A.; Doughty, L.; Hattarki, M.; Coley, A.M.; Casey, J.L.; Anders, R.F.; Foley, M.; et al. Selection and affinity maturation of IgNAR variable domains targeting Plasmodium falciparum AMA1. Proteins 2004, 55, 187-197.

270. Streltsov, V.A.; Varghese, J.N.; Carmichael, J.A.; Irving, R.A.; Hudson, P.J.; Nuttall, S.D. Structural evidence for evolution of shark Ig new antigen receptor variable domain antibodies from a cell-surface receptor. Proc. Natl. Acad. Sci. USA 2004, 101, 12444-12449.

271. Choudhry, V.; Zhang, M.-Y.; Dimitrova, D.; Prabakaran, P.; Dimitrov, A.S.; Fouts, T.R.; Dimitrov, D.S. Antibody-based inhibitors of HIV infection. Expert Opin. Biol. Ther. 2006, 6, 523-531.

272. Chen, W.; Dimitrov, D.S. Human monoclonal antibodies and engineered antibody domains as HIV-1 entry inhibitors. Curr. Opin. HIV AIDS 2009, 4, 112-117.

273. Holliger, P.; Hudson, P.J. Engineered antibody fragments and the rise of single domains. Nat. Biotechnol. 2005, 23, 1126-1136.

274. Albrecht, H.; Burke, P.A.; Natarajan, A.; Xiong, C.-Y.; Kalicinsky, M.; DeNardo, G.L.; DeNardo, S.J. Production of soluble ScFvs with C-terminal-free thiol for site-specific conjugation or stable dimeric ScFvs on demand. Bioconjug. Chem. 2004, 15, 16-26.

275. Lu, D.; Jimenez, X.; Zhanga, H.; Atkins, A.; Brennanb, L.; Balderes, P.; Bohlend, P.; Witte, L.; Zhu, Z. Di-diabody: A novel tetravalent bispecific antibody molecule by design. J. Immunol. Methods 2003, 279, 219-232.

276. Robinson, M.K.; Doss, M.; Shaller, C.; Narayanan, D.; Marks, J.D.; Adler, L.P.; González Trotter, D.E.; Adams, G.P. Quantitative immuno-positron emission tomography imaging of HER2-positive tumor xenografts with an iodine-124 labeled anti-HER2 diabody. Cancer Res. 2005, 65, 1471-1478.

277. Olafsen, T.; Cheung, C.-W.; Yazaki, P.J.; Li, L.; Sundaresan, G.; Gambhir, S.S.; Sherman, M.A.; Williams, L.E.; Shively, J.E.; Raubitschek, A.A.; et al. Covalent disulfide-linked anti-CEA diabody allows site-specific conjugation and radiolabeling for tumor targeting applications. Protein Eng. Des. Sel. 2004, 17, 21-27. 
278. Hu, S.; Shively, L.; Raubitschek, A.; Sherman, M.; Williams, L.E.; Wong, J.Y.C.; Shively, J.E.; Wu, A.M. Minibody: A novel engineered anti-carcinoembryonic antigen antibody fragment (single-chain Fv-CH3) which exhibits rapid, high-level targeting of xenografts. Cancer Res. 1996, 56, 3055-3061.

279. Nakamura, T.; Peng, K.-W.; Vongpunsawad, S.; Harvey, M.; Mizuguchi, H.; Hayakawa, T.; Cattaneo, R.; Russell, S.J. Antibody-targeted cell fusion. Nat. Biotechnol. 2004, 22, 331-336.

280. Brignole, C.; Pastorino, F.; Marimpietri, D.; Pagnan, G.; Pistorio, A.; Allen, T.M.; Pistoia, V.; Ponzoni, M. Immune cell-mediated antitumor activities of GD2-targeted liposomal c-myb antisense oligonucleotides containing CpG motifs. J. Natl. Cancer Inst. 2004, 96, 1171-1180.

281. van Broekhoven, C.L.; Parish, C.R.; Demange, C.; Britton, W.J.; Altin, J.G. Targeting dendritic cells with antigen-containing liposomes: A highly effective procedure for induction of antitumor immunity and for tumor immunotherapy. Cancer Res. 2004, 64, 4357-4365.

282. Sharma, S.K.; Barbara Pedley, R.; Bhatia, J.; Boxer, G.M.; El-Emir, E.; Qureshi, U.; Tolner, B.; Lowe, H.; Paul Michael, N.; Minton, N.; et al. Sustained tumor regression of human colorectal cancer xenografts using a multifunctional mannosylated fusion protein in antibody-directed enzyme prodrug therapy. Clin. Cancer Res. 2005, 11, 814-825.

283. Cortez-Retamozo, V.; Backmann, N.; Senter, P.D.; Wernery, U.; De Baetselier, P.; Muyldermans, S.; Revets, H. Efficient cancer therapy with a nanobody-based conjugate. Cancer Res. 2004, 64, 2853-2857.

284. Holt, L.J.; Herring, C.; Jespers, L.S.; Woolven, B.P.; Tomlinson, I.M. Domain antibodies: Proteins for therapy. Trends Biotechnol. 2003, 21, 484-490.

285. Ryckaert, S.; Pardon, E.; Steyaert, J.; Callewaert, N. Isolation of antigen-binding camelid heavy chain antibody fragments (nanobodies) from an immune library displayed on the surface of Pichia pastoris. J. Biotechnol. 2010, 145, 93-98.

286. Muyldermans, S.; Baral, T.N.; Cortez Retamozzo, V.; De Baetselier, P.; De Genst, E.; Kinnec, J.; Leonhardt, H.; Magez, S.; Nguyen, V.K.; Revets, H.; et al. Camelid immunoglobulins and nanobody technology. Vet. Immunol. Immunopathol. 2009, 128, 178-183.

287. Vandenbroucke, K.; de Haard, H.; Beirnaert, E.; Dreier, T.; Lauwereys, M.; Huyck, L.; Van Huysse, J.; Demetter, P.; Steidler, L.; Remaut, E.; et al. Orally administered L. lactis secreting an anti-TNF Nanobody demonstrate efficacy in chronic colitis. Mucosal. Immunol. 2010, 3, 49-56.

288. Sanz, L.; Blanco, B.; Alvarez-Vallina, L. Antibodies and gene therapy: Teaching old 'magic bullets' new tricks. Trends Immunol. 2004, 25, 85-91.

289. Afanasieva, T.A.; Wittmer, M.; Vitaliti, A.; Ajmo, M.; Neri, D.; Klemenz, R. Single-chain antibody and its derivatives directed against vascular endothelial growth factor: Application for antiangiogenic gene therapy. Gene Ther. 2003, 10, 1850-1859.

290. Blanco, B.; Holliger, P.; Vile, R.G.; Álvarez-Vallina, L. Induction of human T lymphocyte cytotoxicity and inhibition of tumor growth by tumor-specific diabody-based molecules secreted from gene-modified bystander cells. J. Immunol. 2003, 171, 1070-1077.

291. Jendreyko, N.; Popkov, M.; Beerli, R.R.; Chung, J.; McGavern, D.B.; Rader, C.; Barbas, C.F., III. Intradiabodies, bispecific, tetravalent antibodies for the simultaneous functional knockout of two cell surface receptors. J. Biol. Chem. 2003, 278, 47812-47819. 
292. Grosse-Hovest, L.; Wick, W.; Minoia, R.; Weller, M.; Rammensee, H.-G.; Brem, G.; Jung, G. Supraagonistic, bispecific single-chain antibody purified from the serum of cloned, transgenic cows induces T-cell-mediated killing of glioblastoma cells in vitro and in vivo. Int. J. Cancer 2005, 117, 1060-1064.

293. Chambers, R.S. High-throughput antibody production. Curr. Opin. Chem. Biol. 2005, 9, 46-50.

294. McKeating, J.A.; Gow, J.; Goudsmit, J.; Pearl, L.H.; Mulder, C.; Weiss, R.A. Characterization of HIV-1 neutralization escape mutants. AIDS 1989, 3, 777-784.

295. Keck, Z.Y.; Li, S.H.; Xia, J.; von Hahn, T.; Balfe, P.; McKeating, J.A.; Witteveldt, J.; Patel, A.H.; Alter, H.; Rice, C.M.; et al. Mutations in hepatitis C virus E2 located outside the CD81 binding sites lead to escape from broadly neutralizing antibodies but compromise virus infectivity. J. Virol. 2009, 83, 6149-6160.

296. Zharikova, D.; Mozdzanowska, K.; Feng, J.; Zhang, M.; Gerhard, W. Influenza type A virus escape mutants emerge in vivo in the presence of antibodies to the ectodomain of matrix protein 2. J. Virol. 2005, 79, 6644-6654.

297. Prabakaran, M.; Prabhu, N.; He, F.; Qian, H.; Ho, H.-T.; Qiang, J.; Meng, T.; Goutama, M.; Kwang, J. Combination therapy using chimeric monoclonal antibodies protects mice from lethal H5N1 infection and prevents formation of escape mutants. PLoS One 2009, 4, e5672.

298. Haurum, J.S. Recombinant human polyclonal antibodies: A new class of therapeutic antibodies against viral infections. Curr. Pharm. Des. 2006, 12, 2007-2015.

299. de Kruif, J.; Bakker, A.B.H.; Marissen, W.E.; Arjen Kramer, R.; Throsby, M.; Rupprecht, C.E.; Goudsmit, J. A human monoclonal antibody cocktail as a novel component of rabies postexposure prophylaxis. Annu. Rev. Med. 2007, 58, 359-368.

300. Elliott, E.V.; Pindar, A.; Stevenson, F.K.; Stevenson, G.T. Synergistic cytotoxic effects of antibodies directed against different cell surface determinants. Immunology 1978, 34, 405-409.

301. Hellstrom, I.; Brown, J.P.; Hellstrom, K.E. Monoclonal antibodies to two determinants of melanoma-antigen p97 act synergistically in complement-dependent cytotoxicity. J. Immunol. 1981, 127, 157-160.

302. Ziegler-Heitbrock, H.W.; Reiter, C.; Trenkmann, J.; Fütterer, A.; Riethmüller, G. Protection of mice against tetanus toxin by combination of two human monoclonal antibodies recognizing distinct epitopes on the toxin molecule. Hybridoma (Larchmt) 1986, 5, 21-31.

303. Bakker, A.B.; Python, C.; Kissling, C.J.; Pandyad, P.; Marissen, W.E.; Brinka, M.F.; Lagerwerf, F.; Worsta, S.; van Corven, E.; Kostense, S.; et al. First administration to humans of a monoclonal antibody cocktail against rabies virus: Safety, tolerability, and neutralizing activity. Vaccine 2008, 26, 5922-5927.

304. Mascola, J.R.; Louder, M.K.; VanCott, T.C.; Sapan, C.V.; Lambert, J.S.; Muenz, L.R.; Bunow, B.; Birx, D.L.; Robb, M.L. Potent and synergistic neutralization of human immunodeficiency virus (HIV) type 1 primary isolates by hyperimmune anti-HIV immunoglobulin combined with monoclonal antibodies 2F5 and 2G12. J. Virol. 1997, 71, 7198-7206.

305. Armbruster, C.; Stiegler, G.M.; Vcelar, B.A.; Jäger, W.; Köller, U.; Jilch, R.; Ammann, C.G.; Pruenster, M.; Stoiber, H.; Katinger, H.W.D. Passive immunization with the anti-HIV-1 human monoclonal antibody (hMAb) 4E10 and the hMAb combination 4E10/2F5/2G12. J. Antimicrob. Chemother. 2004, 54, 915-920. 
306. Trkola, A.; Kuster, H.; Rusert, P.; Joos, B.; Fischer, M.; Leemann, C.; Manrique, A.; Huber, M.; Rehr, M.; Oxenius, A.; et al. Delay of HIV-1 rebound after cessation of antiretroviral therapy through passive transfer of human neutralizing antibodies. Nat. Med. 2005, 11, 615-622.

307. Spiridon, C.I.; Ghetie, M.-A.; Uhr, J.; Marches, R.; Li, J.-L.; Shen, G.-L.; Vitetta, E.S. Targeting multiple Her-2 epitopes with monoclonal antibodies results in improved antigrowth activity of a human breast cancer cell line in vitro and in vivo. Clin. Cancer Res. 2002, 8, 1720-1730.

308. Strauss, S.J.; Morschhauser, F.; Rech, J.; Repp, R.; Solal-Celigny, P.; Zinzani, P.L.; Engert, A.; Coiffier, B.; Hoelzer, D.F.; Wegener, W.A.; et al. Multicenter phase II trial of immunotherapy with the humanized anti-CD22 antibody, epratuzumab, in combination with rituximab, in refractory or recurrent non-Hodgkin's lymphoma. J. Clin. Oncol. 2006, 24, 3880-3886.

309. Nowakowski, A.; Wang, C.; Powers, D.B.; Amersdorfer, P.; Smith, T.J.; Montgomery, V.A.; Sheridan, R.; Blake, R.; Smith, L.A.; Marks, J.D. Potent neutralization of botulinum neurotoxin by recombinant oligoclonal antibody. Proc. Natl. Acad. Sci. USA 2002, 99, 11346-11350.

310. Jefferis, R. Glycosylation of recombinant antibody therapeutics. Biotechnol. Prog. 2005, 21, 11-16.

311. Burton, D.R.; Desrosiers, R.C.; Doms, R.W.; Koff, W.C.; Kwong, P.D.; Moore, J.P.; Nabel, G.J.; Sodronski, J.; Wilson, I.A.; Wyatt, R. HIV vaccine design and the neutralizing antibody problem. Nat. Immunol. 2004, 5, 233-236.

312. Marasco, W.A.; Sui, J. The growth and potential of human antiviral monoclonal antibody therapeutics. Nat. Biotechnol. 2007, 25, 1421-1434.

313. Brock, T.D., Ed. Milestones in Microbiology, 1556-1940; ASM Press: Washington DC, USA, 1998.

314. Casadevall, A.; Scharff, M.D. Serum therapy revisited: Animal models of infection and development of passive antibody therapy. Antimicrob. Agents Chemother. 1994, 38, 1695-1702.

315. Logtenberg, T. Antibody cocktails: Next-generation biopharmaceuticals with improved potency. Trends Biotechnol. 2007, 25, 390-394.

316. Glassy, M.C.; McKnight, M. The rate-limiting step in obtaining human monoclonal antibody drug pharmaceuticals. Expert Opin. Investig. Drugs 1995, 4, 225-228.

(C) 2013 by the authors; licensee MDPI, Basel, Switzerland. This article is an open access article distributed under the terms and conditions of the Creative Commons Attribution license (http://creativecommons.org/licenses/by/3.0/). 